\title{
THE UNIQUE RECORD OF ZA HÁJOVNOU CAVE
}

\author{
RUDOLF MUSIL
}

Inst. of Geological Sciences, Faculty of Science, Masaryk university Brno, the Czech Republic, rudolf@sci.muni.cz

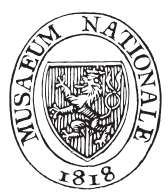

Musil R. (2014): The unique record of Za Hájovnou Cave. - Acta Mus. Nat. Pragae, Ser. B, Hist. Nat, 70(1-2): 7-26, Praha. ISSN 1804-6479.

Abstract. The cave Za Hájovnou is a former sinkhole. It was active from the Early Pleistocene until the beginning of the Cromerian Interglacials complex. This publication assesses the sediments of the two main corridors, the Vykopaná chodba and the Narozeninová chodba. Only two exposures have been found with sediments from the Last Interglacial (Eemian) and from the Last Glacial. The sediments come mostly from the Middle Pleistocene. The layer sequences of the two corridors are different. It is possible to classify all the Middle Pleistocene sediments into two distinct groups. Both groups were formed in a warm interglacial climate and differ in conservation of the osteological material due to the different sedimentary content. In the Narozeninová chodba, these groups are separated by a large talus cone. The most important question is if there were one or more interglacials in the Middle Pleistocene here. Both alternatives are discussed in this paper.

Javoříčko Karst, Za Hájovnou Cave, Middle Pleistocene, cave exposures, Holsteinian Interglacial problems, zoopalaeontology, palynology.

Received January 20, 2014

Issued October, 2014

\section{Introduction}

Za Hájovnou Cave is an important geological and palaeontological site. The Early Pleistocene fluvial deposits overlain by non fluvial sediments containing a large quantity of vertebrates and pollen are predominantly from the Middle Pleistocene. Such finds of this age are very rare in Moravia. Here we describe all the profiles, some of which were sampled for zoopalaeontological and palynological study. In the cave there are two main parallel corridors (Text-fig. 1). All discussed exposures marked as ZH P come from these two corridors and from adjacent passages (altogether 13). We can now place several important sedimentological and stratigraphical events within the depositional history of the site, above all from warm events (interglacials) of the Middle Pleistocene. These results may be importatnt for inter-regional stratigraphic correlation of the Middle Pleistocene of Central Europe.

\section{Topography}

The Za Hájovnou Cave $\left(49^{\circ} 40^{\prime} \mathrm{N}, 16^{\circ} 55^{\prime} \mathrm{E}\right)$ is situated in northern Moravia (the Czech Republic), within the territory of Javořičko Karst (Text-fig. 2). The Javoříčko Karst is a relatively small area formed by Devonian (Eifelian-Frasnian), light-grey-coloured massive limestone. The limestone is disrupted by NW-SE and SW-NE dislocations along which most of the caves developed.

Two rivers, Špraněk and Javoříčka, flow through the karst. The Za Hájovnou Cave is situated on the north-western bank of the Javoříčka river on the southern side of Paní Hora hill (which rises to 485 m a.s.1.).

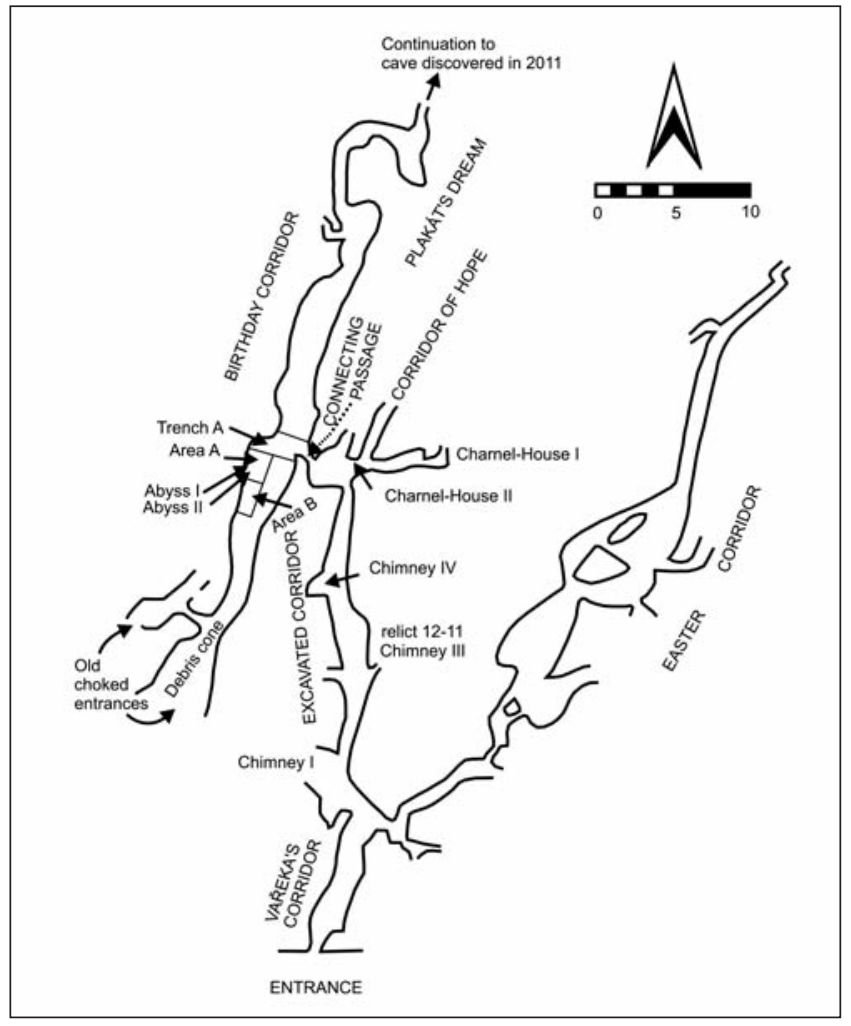

Text-fig. 1. A plan of the passages of Za Hájovnou Cave in which individual sections were studied. After A. Tomica, with complements. Abyss I and II = Propástka 1 and 2; Birthday Corridor $=$ Narozeninová chodba; Charnell-House (Kostnice) $I$ and II = Chimney I-IV = Komín I-IV; Connecting Passage $=$ Spojovací chodba; Corridor of Hope = Chodba naděje; Easter Corridor $=$ Velikonoční jeskyně; Excavated Corridor $=$ Vykopaná chodba; Plakát's dream = Plakátův sen; Vařek's Corridor $=$ Vařekova chodba. 


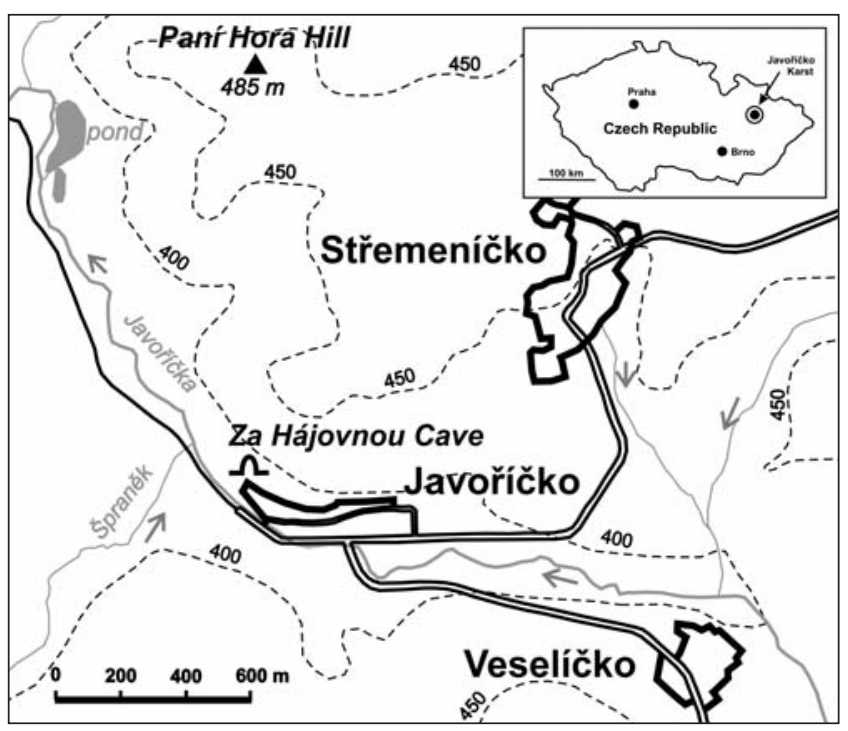

Text-fig. 2. The territory of Paní Hora hill under investigation. The area of Javořičcko Karst containing Javoříčko, Veselíčko and Stř̌emeníčko villages.

\section{History of Research}

The Institute of Geological Sciences of Masaryk Univerzity, Brno began research in Za Hájovnou Cave (Moravia, the Czech Republic) in the year 2001. From this time it has been an on-going activity. Field research there has served also as hands-on training for university students. The acquired zoopalaeontological material is deposited in the Institute Anthropos in the Moravian Museum

The first complex processing of results were published in 2005 (the periodical Prrírodovědné studie Muzea Prostějovska, vol. 8, pp. 186). The papers were initially connected with biostratigraphic (Ábelová 2005, Doláková 2005, Ivanov 2005, Musil 2005a, b, Sabol 2005, Wagner 2005), with palaeopathology of bones (Nývltová 2005) and palaeomagnetic data (Kadlec et al. 2005). Other papers treated of natural radioactivity (Štelcl, Zimák 2005), geochemistry (Zeman 2005), sedimentology (Lisá 2005) and minerals of sediments (Čatloš, Fejdi 2005). The next publication concerned with $\mathrm{U} / \mathrm{Th}$ dating of strata came out in the periodical "Quaternary International" (Lundberg et al. 2014). Since these first publications, a large amount of new knowledge has accumulated (13 exposures): in particular focused on the process of deposition, further zoopaleontological and palynological finds.

\section{Methods}

Electric lighting was installed in the cave which allowed better orientation with respect to the layers. A lift was installed for easier transport of sediments from the cave.

The sediments were removed from the individual layers. If the layer was thicker, then from separate horizons. When the sediment was in the open, it was inspected and any bones found were put into bags and marked with the exposure number and the layer. A record was made in the work diary including a detailed description not only of the sediment but also of all the finds in it. The finds were taken away for laboratory study. All documentation was supplemented with drawing and photographic attachments.

Some of the sediment was transported to a water source where it was floated on screens with a mesh size of 1.0 and $0.5 \mathrm{~mm}$. The obtained material was then dried and bagged with a record of where it was found.

When all the field work was completed, the other work was then carried out in the laboratory. Bones were prepared for professional study by individual specialists.

At some exposures I also conducted magnetic susceptibility testing. This task was to identify the extent to which its findings could serve to distinguish the individual layers. Magnetic susceptibility appeared very useful for dividing individual layers if there were unclear boundaries. It was carried out only on three profiles, ZH P-5 (layers of 2a, 2b, 3a, 3b, 4, 5-8), ZH P-9 (layers 2-5) and the ZH P-11 (layer $3 b, 4)$.

\section{Geological and paleontological background}

The deposits were studied from geological and palaeobiological standpoints. With regard to layer numbering in individual profiles, the same numbers don't always mean the same layer and time. Therefore, the individual exposures have sometimes a varying number of different layers. (A set of all the categories used in drawing the profiles is presented in Text-fig. 3).

The results of zoopaleontological and palynological study are published in separate articles. Paleontological determination follows: Ivanov (2005), Ivanov and Vöröš (2014), Sabol and Zervanová (2014) (microfauna), Wagner (2005), Musil (2005b), Sabol (2014) (large fauna), and Doláková (2005, 2014) (palynology).

\section{Major exposures}

Junction between Vykopaná chodba (= Excavated Corridor) and Velikonoční jeskyně (= Easter Corridor) Profiles ZH P-1 (upper part of Komín I (= Chimney I), Vykopaná chodba) and ZH P-2 (lower part of Komín I, Velikonoční jeskyně)

\section{Profile ZH P-1 (Vykopaná chodba)}

\section{Complex IV (layers 1-5)}

Layer 1. Large limestone blocks (100\%) almost fill the chimney. The thickness is unknown, but from the base of this layer towards the surface is ca. $6.5 \mathrm{~m}$. The overburden of blocks are probably deposits, from the beginning of the Holocene.

Layer 2. Loessic loam of yellow-brown colour, a great number of small sharp edged pieces of debris (about 60-70\%), with occassional larger pieces. Extremely cool climate. Calcareous nodules. In the overlying, cave bottom sinter. Thickness $120 \mathrm{~cm}$.

Layer 3. Yellow-brown loessic loam, large size debris (20-25 cm on average, 20\%). A small number of scattered bone splitters. Thickness $100 \mathrm{~cm}$. 


\begin{tabular}{|l}
\hline$\Delta \Delta \quad$ Cave bottom sinter, mostly $2-3 \mathrm{~cm}$ thick. \\
Fragments of needle-shaped calcite crystalline aggregates. \\
Fragments of sinter crust of various size and thickness. \\
Loam sinter (loam with CaCO ${ }_{3}$ content, which forms various \\
sized hard agglutinates (clusters)). Usually grey. \\
Loam oval raddles (fine grained loam, diameter usually \\
about 5 cm, thin laminations of various colours). \\
Manganese nodules or buckshot gravels (oxides and hydro- \\
xides), dark or black colour, small size, about 2-3 cm. \\
Calcareous nodules (relatively similar to loess nodules, \\
some hollow, others solid). \\
B
\end{tabular}

Text-fig. 3. Key to categories used in section drawings.

Layer 4. Yellow-brown loessic loam, containing small sized sharp edged debris (50-60\%), with occassional larger pieces. Without calcareous nodules. Extremely cool climate. The development is similar to layer 2 . Thickness $150 \mathrm{~cm}$.

Layer 5. Yellow-brown loessic loam, a great number of medium sized pieces of debris (up to $50 \%$ ). Similar to layer 3. Thickness $300 \mathrm{~cm}$.

Complex IV comprises a uniform unit of the same loessic loam. The individual layers differ only in the varying amount of debris and its size. Between complex IV and III we must assume a long depositional hiatus. The total thickness of layers $2-5$ is $670 \mathrm{~cm}$.

Zoopaleontological finds: In layer 3 unidentifiable small fragments of bone.

There is a depositional hiatus between the layer 5 of ZH P-1 and layer 6 of ZH P-2.

\section{Profile ZH P-2 (Velikonoční jeskyně) (continuing from Profile $\mathrm{ZH} \mathrm{P-1)}$}

\section{Complex III (layer 6)}

The deposits and their origin are quite different from the overlying layers. In general they don't usually extend across the whole profile. The method of deposition was different

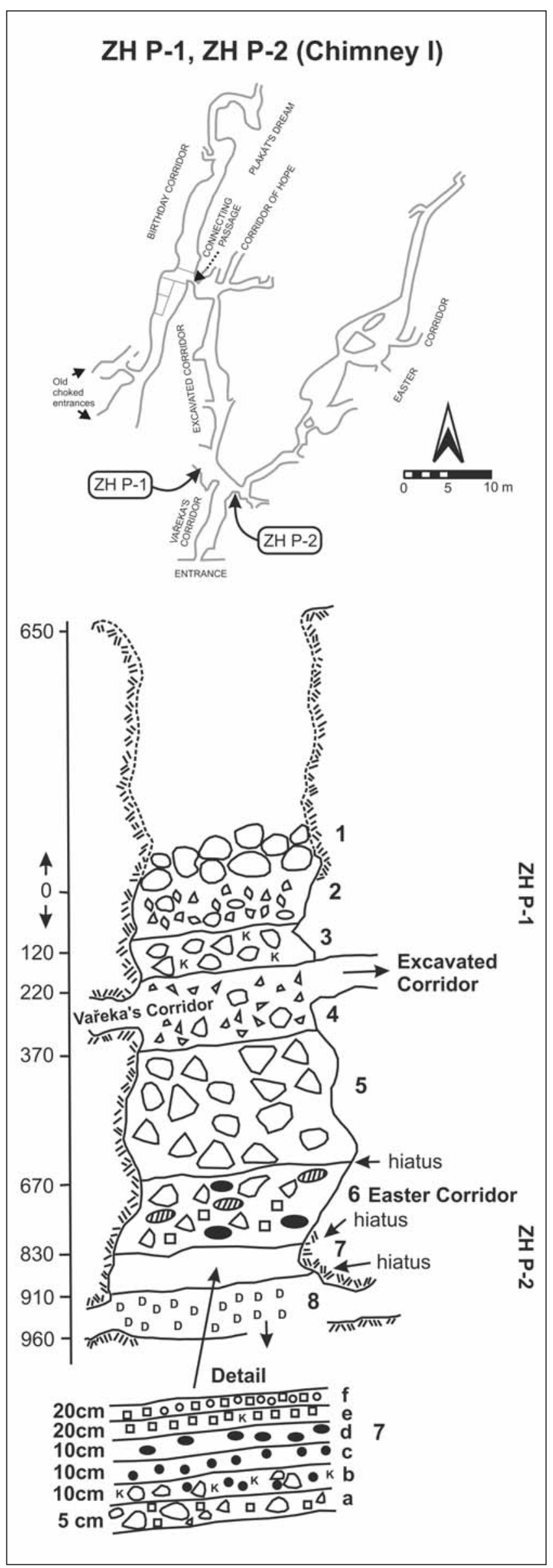

Text-fig. 4. Za Hájovnou Cave. Section ZH P-1 (Vykopaná chodba = Excavated Corridor) and ZH P-2 (Velikonoční jeskyně = Easter Corridor), Komín I (= Chimney I). 
from that in complex IV. Frequent horizons of water born sediments.

Layer 6. Clayey sandy matrix of russet to reddish-brown colours. Larger debris towards the base and more abundant. The layer is sharply separated from the underlying bed. In the upper part of the layer are loam sinters. In all thickness frequent subangular detritus of vein quartz (30\%), large and small manganese nodules (oxides and hydroxides) on average about $2 \mathrm{~mm}$ in diameter. As far as to the base of this layer, the limestone rock faces show strong chemical and physical erosion, further downwards this is not evident. No water and aerial erosion on the rock faces. Therefore, it appears that the part from the base of layer 6 upwards wasn't filled with sediment for some extended time. The surface of layer 7 formed the upper border of sedimentational filling for some considerable time. Value of magnetic susceptibility in the upper part: $0.25,0.33,0.35$, in the bottom part: $0.41,0.43,1.51$. Thickness $165 \mathrm{~cm}$. This layer is slightly similar to profile $\mathrm{ZH}$ $\mathrm{P}-5$, layers $2 \mathrm{a}$ and $2 \mathrm{~b}$.

Zoopaleontological finds:

Large mammals: Indeterminable bones of adult bears and neonates (Ursus sp.). One bone was gnawed by a wolf or bear.

Rodents: Microtus gregalis, Microtus oeconomus, Microtus arvalis/agrestis group, Clethrionomus glareolus, Lemmus lemmus, Dicrostonyx cf. torquatus, Arvicola cantiana, Arvicola terrestris (Ivanov 2005).

There is a depositional hiatus between the layer 6 and 7 .

\section{Complex II (layers 7f -7a)}

Group of strata of various thicknesses in colours of very different sediments. They don't extend over the whole profile, sometimes only as interfingering lenses. It is possible to divide the whole layer into a number of horizons. Large amount of microfauna (voles, snakes, but arctic lemmings are missing).

From top down:

Layer 7f. Light grey clayey matrix without limestone debris. Fragments of vein quartz, small quartz chesils (5\%). Thickness $20 \mathrm{~cm}$.

Layer 7e. Grey clayey matrix without limestone debris, gradual transition to overlying. Fragments of vein quartz (5-100\%). Thickness $20 \mathrm{~cm}$. Value of magnetic susceptibility of $7 \mathrm{f}$ and $7 \mathrm{e}: 0.19$ and 0.21 .

Zoopaleontological finds: Bones of bears.

Layer 7d. Clayey silt of light brown colour, without limestone debris, limonitic nodules with diameter ca. $2 \mathrm{~cm}$. Thickness $10 \mathrm{~cm}$.

Layer 7c. Grey clayey matrix, limonitic nodules, on the base interlayers of red clay. Thickness $10 \mathrm{~cm}$. Value of magnetic susceptibility of $7 \mathrm{c}$ and $7 \mathrm{~d}: 0.22,0.29,0.34$.

Layer 7b. Brown coloured clayey silt, limestone debris up to $10 \mathrm{~cm}$ in size $(5 \%)$, many small $\mathrm{Mg}$ or Fe nodules. Thickness $10 \mathrm{~cm}$.

Zoopaleontological finds: Bones of bears.

Layer 7a. Clayey silt of greyish brown colour with small and large debris, vein quartz. Thickness $5 \mathrm{~cm}$. Value of magnetic susceptibility of $7 \mathrm{a}$ and $7 \mathrm{~b}: 0.37$.

Complex II forms a coherent unit quite different from the roof. Several times intermittent settling of layers within this complex result in two quite different parts, the lower one ( $7 \mathrm{a}$ plus $7 \mathrm{~b}$ with debris) and the upper one (7c as far as $7 \mathrm{f}$ ). without debris. Deposition of the upper layers probably occurred within a relatively short time. No reason for uninterrupted settling was identified.

Zoopaleontological finds: In layers $7 \mathrm{~b}$ and $7 \mathrm{e}$ bones of bears (Ursus sp.). Findings of reptiles and amphibians from the entire layer 7: Bufo viridis, Lacerta cf. agilis, Coronella austriaca, Vipera berus (mostly). The following rodent species were found: Microtus gregalis, Microtus oeconomus, Microtus arvalis/agrestis, Clehtrionomys glareolus, Lemmus lemmus, Dicrostonyx cf. torquatus.

Layer 7ab: Microtus arvalis/agrestis group, Microtus gregalis, Microtus oeconomus, Dicrostonyx cf. torquatus.

Layer 7cd: Within this layer the assemblage composition is similar to the basal layer. Microtus gregalis, Microtus oeconomus, Microtus arvalis-agrestis group, Clethrionomys glareolus, Dicrostonyx cf. torquatus.

Layer 7ef: Microtus gregalis, Microtus arvalis-agrestis group, Clethrionomys glareolus, Lemmus lemmus (Ivanov 2005).

Palynological spectrum: From sediments $50 \mathrm{~cm}$ above the base of layer 7 (i.e. layer 7e) the palynomorpha are limited to herbs. No tree pollen or large pollen grains were observed (Doláková 2014).

There is a depositional hiatus between the layer 7 and 8 .

\section{Complex I (layer 8)}

Layer 8. Highly disintegrating culm greywackes (100\%) easily crushed. At the base agglutinated oxides and hydroxides of $\mathrm{Mg}$ and $\mathrm{Fe}$. Sometimes narrow sandy clay layers. In the roof a weak horizont of laminated clay. Without limestone debris. Visible thickness $50 \mathrm{~cm}$.

Summary: Most of layers from Profiles ZH P-1 and ZH P-2 have no analogy with other exposures.

\section{Vykopaná chodba (= Excavated Corridor)}

\section{Profile ZH P-3 (between Komín II (= Chimney II) and Komín III (= Chimney III), relict 12-11)}

Relict of clayey silt in the upper part of this karstic chimney, originally probably filling this part of the horizontal Vykopaná chodba. The deposits were displaced by speleological work.

Layer 1. Alternating thin layers of thinly laminated deposits of double colours (infiltration cave sediments), darker brown and brick red with brown loamy sediment. In the upper part a thin horizontal sinter layer. Evidently cyclic interruptions of sediment settling.

Layer 2. The sediment of yellow-brown to darker-brown colours sharply separated from the roof. Almost without limestone debris (infiltration cave sediments). Thickness $40 \mathrm{~cm}$.

Zoopaleontological finds: A small number of bones, bone beds, a great many well preserved shells of larger gastropods of various species (Helicigona banatica), Ursus cf. deningeri, bats, rodents, insectivores, reptiles.

Layer 3. On the top cave bottom sinter. Brown loose sediment almost without limestone debris. In the sediment 


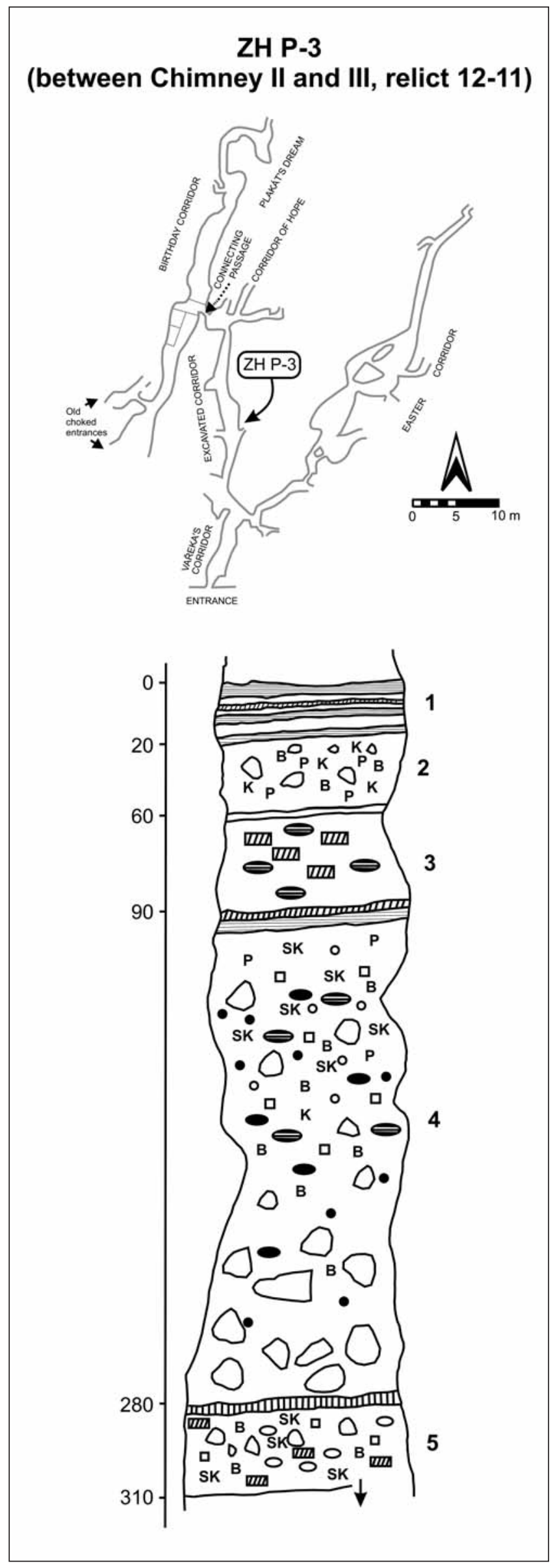

Text-fig. 5. Za Hájovnou Cave. Section ZH P-3 (Vykopaná chodba (= Excavated Corridor), between Komín II and III (= Chimney II and III), relict 12-11). fragments of brown coloured cave bottom sinters. Loam sinters with thin laminations of rusty and brown colours. Bones in upper half only, elsewhere only a few. Thickness $30 \mathrm{~cm}$.

Zoopaleontological finds: Ursus cf. deningeri (Wagner 2005), Panthera fossilis (Sabol 2014), Canis sp.

Layer 4 In the roof the cave bottom sinter and a layer $(2 \mathrm{~cm})$ of thinly laminated clayey loam of brick red colour. Yellow- brown loessic loam lighter than the roof, and sharply separated from it. Relatively disintegrated limestone debris $(2 \%)$, with sinter crust. Bones only in upper part. The bone surfaces are black with a sinter crust. The sinter crust on the surface of bones reflects greater precipitation. Interestingly in the upper part a few fragments of vein quartz and small quartz chesils. Loam raddles of brick red colour, size up to $5 \mathrm{~cm}$. Manganese nodules $5 \mathrm{~cm}$ in diameter, manganese small buckshot gravels. Bone beds (breccia).

Zoopaleontological finds: Ursus cf. deningeri, Panthera fossilis, Rupicapra sp. Bones of reptiles Anquis fragilis, Elaphe longissima, cf. Natrix sp.

Layer 5. In the roof of this layer cave bottom sinter. Sienna loessic loam lighter than overlying layer from which it is distinctly separated. It evidently documents a xeric perhaps as well as cold climate. A small amount of limestone debris. Fragments of vein quartz. A large number of calcareous nodules different in lengthwise form with proportions $15 \times 10 \times 20 \mathrm{~mm}$ or larger. A small number of bone beds (breccia). The surface of bones is mostly coated with sinter. The sinter crust on the surface of bones reflects greater precipitation. Fragments of cave bottom sinters of a brown colour. The base of the layer wasn't detected.

Analogy: The sediment is similar to theVykopaná chodba, Kostnice I (= Charnel-House I), profile ZH P-6, layer 2.

\section{Profile ZH P-4}

There is cave bottom sinter approximately $4 \mathrm{~m}$ in front of Kostnice II (= Charnel-House II), just under the roof. The underlying deposits were displaced by speleological work. Regarding the proximity of Kostnice II and from the statements of the speleologists, we can assume with some certainty that these are the same deposits as in profile $\mathrm{ZH}$ P-5. 2014)

U/Th dating: Basis $224 \pm 4$ ka (MIS 7) (Lundberg et al.

\section{Profile ZH P-5, Kostnice II (supporting standard profile)}

Layer 1a. Fine clayey thinly laminated deposit of light-brown colour (thickness of lamina 1-3 mm). Without limestone debris. On the upper side thin layer of porous dust (loessic loam?) (infiltration cave sediments). Fragments of needle calcite crystalline aggregates.

Zoopaleontological finds: unidentified microfauna.

Layer 1b. Clayey laminated deposit of dark- brown colour, without limestone debris. The base mirrors the uneven underlying bed. Possible annual deposition (infiltration cave sediments). Thickness of both $1 \mathrm{a}$ and $1 \mathrm{~b}$ layers $40 \mathrm{~cm}$. 


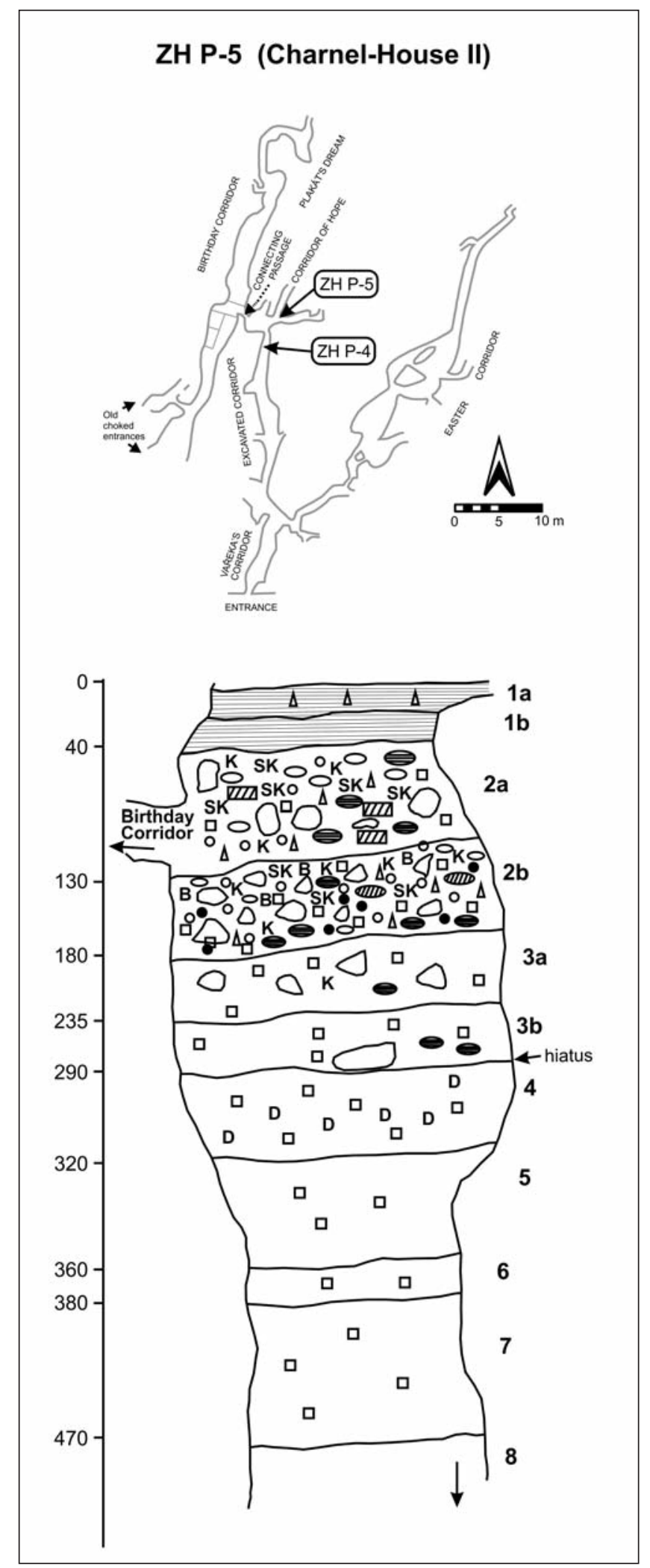

Text-fig. 6. Za Hájovnou Cave. Section ZH P-5 (Vykopaná chodba (= Excavated Corridor), Kostnice II (= Charnel-House II)).

Zoopaleontological finds: unidentified microfauna.

Layer 2a. Brown to reddish-brown crumbled clayey silt. Limestone debris of various sizes (up to $50 \mathrm{~cm}$ on average, above $50 \%$ ), with strong corrosion. All the bones are in fragments. On their surface is a mostly brown coloured sinter crust $1-2 \mathrm{~mm}$ thick. It resembles sandstone, but it is not pure
$\mathrm{CaCO}_{3}$. The sinter crust on the surface of the bones reflects greater precipitation. There is a small proportion of bones without sinter on the surface (a ratio of about 8:2). Thinly laminated loam raddles, thickness about $1 \mathrm{~cm}$. Quartz chesils, fragments of vein quartz, fragments of crystalline sinter and of needle calcite crystalline aggregates, fragments of stalactites.

Mineral analysis: rutile, idiomorphic quartz, magnetite, limonitized pyrite, micas (Čatloš and Fejdi 2005). Value of magnetic susceptibility: $0.82-1.95$, average from nine measuring 1.074 .

Zoopaleontological finds: Large quantity of bear bone fragments (Ursus cf. deningeri, furthermore also Panthera fossilis. The sinter crust on the surface of bones reflects greater precipitation.

Palynological spectrum: A layer with multifarious finds of palynospectra: Alnus, Ulmus, Salix, Fraxinus, Juniperus, Picea, Pinus sylvestris (dominant), Pinus cembra, herbs (Doláková 2014).

U/Th dating: isolated fragments of broken sinter, $1 \mathrm{~cm}$ thick, $145 \pm 1$ ka (MIS 6), $267 \pm 3$ ka (MIS 8), (Lundberg et al. 2014)

Layer 2b. Dark-brown clayey cuboid disintegrating sediment. A large number of middle-sized highly corroded limestone debris (up to $80 \%$ ). Flat debris were positioned horizontally. Bones were unevenly distributed. No whole bones were found. Towards the base fewer bones. Only a few bones with surface sinter. They are often completely disintegrated and only teeth are well preserved. However their roots are also disintegrated. Some oval pieces of spongiosa $2-3 \mathrm{~cm}$ on average. Bone beds (breccia) mostly in the upper part. Loam raddles but extremely hard so that in the case of larger sized raddles it was necessary to use a pneumatic hammer to break them. We assume higher precipitation. A large number of quartz chesils $(30 \%$, average size $1-2 \mathrm{~cm})$, a huge number of vein quartz fragments $(30 \%)$, sizes up to $5 \times 10 \mathrm{~cm}$. Fragments of needle calcite crystalline aggregates, many small manganese nodules. The base of the layer wasn't horizontal, but had a wavy form. Value of magnetic susceptibility: 0.32-0.91, average from twelve measurements 0.51 . Thickness $50 \mathrm{~cm}$.

Zoopaleontological finds: Fragments of bear bones. Ursus cf. deningeri (Wagner 2005), Equus sp.

Palynological spectrum: A layer with multifarious finds of palynospectra: Carpinus, Tilia, Alnus, Ulmus, Salix, Fraxinus, Hereda, Pterocarya, Betula, Corylus, Juniperus, Picea, Picea sylvestris (dominant), Pinus cembra and herbs (Doláková 2014).

Layer 3a. Dark-brown solid cuboid clayey silt. Little widely scattered strongly disintegrating limestone debris. Only a few bone fragments. Fragments of vein quartz of various sizes, loam raddles. Thickness $40 \mathrm{~cm}$.

Zoopaleontological finds: Almost without bone fragments.

Layer 3b. Dark-brown to rusty-brown clayey silt, in colour heterogeneous, sandy, not as solid as in the layer above. Almost without limestone debris, on a base of larger limestone blocks. In lower part of layer loam raddles present. Fragments of vein quartz of various sizes.

Mineralogical analysis: garnet, ilmenite, rutile, idiomorphic quartz, magnetite, pyrite, limonitised pyrite, micas (Čatloš and Fejdi 2005). Thickness $15 \mathrm{~cm}$. 
Geochemical study of both layers ( $3 a$ and $3 b$ ) showed, in contrast to other layers, a high content of manganese. The $\mathrm{MnO}$ content exceeded three per cent, in other layers it was only in hundredths of a percent. At the same time an extremely high content of $\mathrm{P}_{2} \mathrm{O}_{5}$ was recorded. The excrescent quantity of $\mathrm{P}_{2} \mathrm{O}_{5}$ had already begun in layer $2 \mathrm{~b}$ (Zeman 2005). Value of magnetic susceptibility of layers $3 \mathrm{a}$ and $3 \mathrm{~b}$ : $0.14-0.60$, average from twelve measurements 0.3225 .

Below this layer are the fluvial deposits.

Zoopaleontological finds: Only solitary small bone fragments, Ursus cf. deningeri.

There is a depositional hiatus between the layers $3 \mathrm{~b}$ and 4 .

Layer 4. Clay-like to sandy fluvial sediments of rustybrown to brown colour. Almost without limestone debris. Those present were highly disintegrating and on their surface had a manganese crust. Disintegrated pebbles of culm greywackes and slates, also fragments of vein quartz, without paleontological finds. The layer is sharply separated from the underlying bed. Thickness $55 \mathrm{~cm}$. Deposits of sinkhole waters.

Mineralogical analysis: garnet, ilmenite, idiomorphic quartz, magnetite, pyrite, limonitised pyrite, micas (Čatloš and Fejdi 2005). Value of magnetic susceptibility: 0.36-0.65, average from thirteen measuring 0.5207 .

Palaeomagnetic dating: B/M boundary (MIS 19, Cromerian Interglacial I) (Kadlec et al. 2005).

Layers 5-8. Fluvial sediments of clayey dust, fragments of vein quartz, without paleontological finds. Layers lateral substitute. (Kadlec et al. 2005, 2014). The base of fluvial sediments not identified.

Value of magnetic susceptibility in layer 5: 0.12-0.24, average from seven measurements 0.1885 . Value of magnetic susceptibility in layers 6 and 7: 0.13-0.19, average from seven measurements 0.1571 . Value of magnetic susceptibility in layer 8: $0.45-0.50$, average from four measurements 0.475 .

Mineralogical analysis: lower part of layer 5: garnet, ilmenite, idiomorphic quartz, magnetite, pyrite, limonitised pyrite, micas, zircon. Lower part of layer 7: garnet, rutile, idiomorphic quartz, magnetite, pyrite, limonitised pyrite, micas, zircon.Upper part of layer 8: garnet, idiomorphic quartz, magnetite, zircon, silver non - magnetic metal. Lower part of layer 8: chlorite, garnet, ilmenite, rutile, idiomorphic quartz, magnetite, pyrite (Čatloš and Fejdi 2005).

Mineralogical composition of non fluvial and fluvial deposits was nearly the same in all layers. Pyrite and garnets occur at a high percentage. Approximately 80-90\% of the light fraction formed by quartz. According to Čatloš and Fejdi (2005) the analysis pointed to only one source region, namely the river Špraněk basin.

Palynological spectrum: Palynologically sterile.

\section{Profile ZH P-6, Kostnice I}

Layer 1. Brown loose clayey silt, solitary with strongly disintegrating limestone debris with manganese crust on the surface, crushable by hand. Bones of adult bears and neonates, in fragments or whole, without sinter crust. Further bones of bisons or oxes, lions and birds. Some bones are lengthwise and crosswise fissured. Deeper bone finds are more disintegrated. Towards the base the amount of finds decreases. Fragments of vein quartz up to $10 \mathrm{~cm}$ on average,

\section{ZH P-6 (Charnel-House I)}
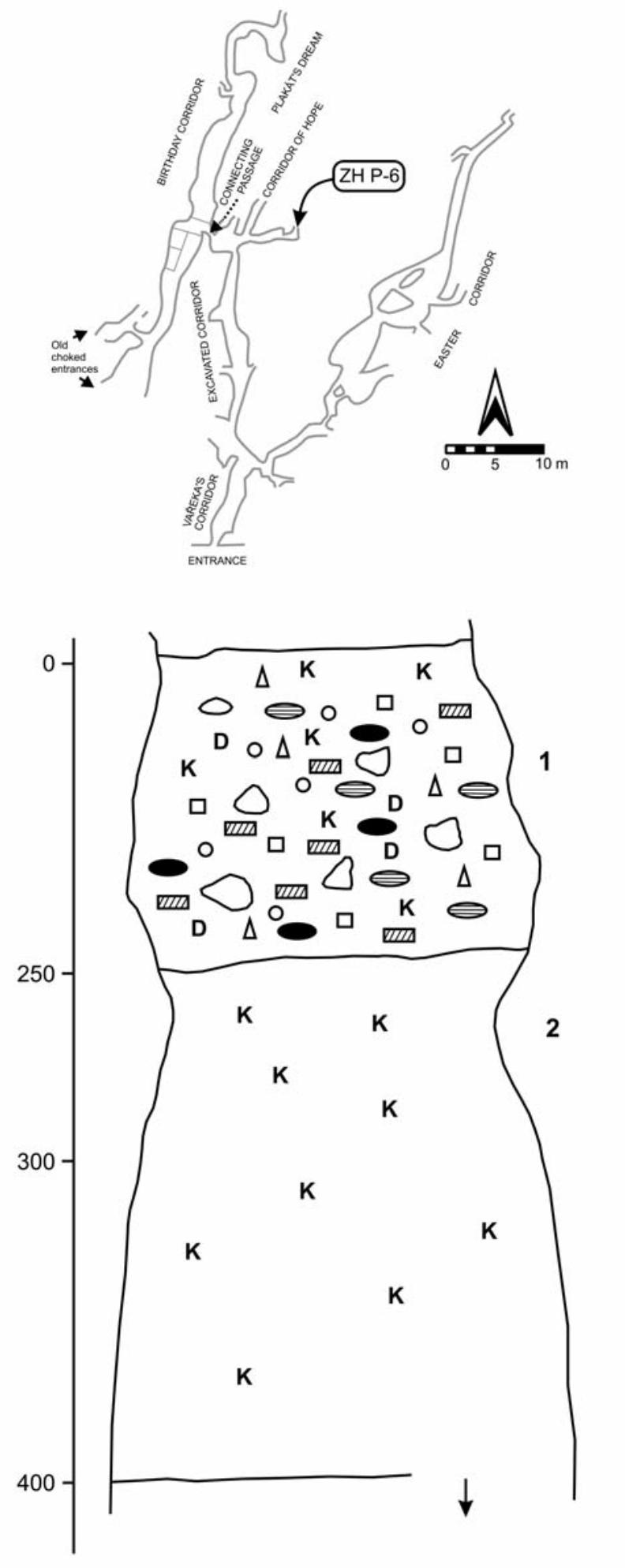

Text-fig. 7. Za Hájovnou Cave. Section ZH P-6 (Vykopaná chodba (= Excavated Corridor), Kostnice I (= Charnel-House I)).

numerous quartz chesils (30-40\%) and pebbles of culm graywackes and slates, fragments of needle calcite crystalline aggregates and thin cave bottom sinter containing quartz chesils. Limonite nodules, loam raddles. At the bottom large fragment of cave bottom sinter (thickness 
$5 \mathrm{~cm}$ ) which is composed only from sinter cementing small quartz chesils. Thickness $250 \mathrm{~cm}$.

Layer 2. Brownish-yellow loessic loam without debris, non-uniform colour. Without a signifiant number of paleontological finds. Those present belong to adult bears and neonates. Bones are in fragments or whole. The depth of the pit being $4 \mathrm{~m}$, the base wasn't identified.

Analogy: Only in exposures ZH P-5 and ZH P-6 were large numbers of needle calcite crystalline aggregate fragments found as well as a signifiant number of quartz chesils. The sediment is similar to layer 4 (Profile ZH P-3, relict 12-11, Vykopaná chodba) and to layer 5, ZH P-9 (Narozeninová chodba (= Birthday Corridor), Propástka 1 and 2 (= Abyss I and II).

Zoopaleontological finds: Fragments and whole bones of bears, without sintered crust. Birds, Ursus ex. gr. deningeri, Panthera fossilis.

\section{Chodba naděje (= Corridor of Hope)}

The Chodba naděje is an elongation of the Vykopaná chodba behind Kostnice II. Its lengh is ca. $4 \mathrm{~m}$. On the right hand side is situated Kostnice I. Deposits are not a homogenous colour and often exchanged with each other so that sometimes they don't cover the whole longitudinal profile. Therefore it is more logical to consider the complex as a mix of different coloured layers of different thicknesses. Lengthwise the profile doesn't have a constant thickness.

\section{Profile ZH P-7a} $1-4)$.

At the front of the corridor, a longitudinal profile (layers

Layer 1. Dark-brown clayey silt without limestone debris. Many calcareous nodules (concretions) of a brown colour. Thickness $40 \mathrm{~cm}$.

Layer 2. Thinly laminated fine sandy sediment with alternating stratulums in yellow and brown colour. Without limestone debris and without calcareous nodules. Distinctly separated from overlying and underlying layers (infiltration cave sediments). Thickness $15-20 \mathrm{~cm}$.

Analogy: Layer 1b, Kostnice II, profile ZH P-5.

Layer 3. Complex of layers of various thicknesses. From top down:

Layer 3a. Brown clayey silt, limestone debris of size of human fist size, fragments of vein quartz. Many disintegrating bones covered with sinter. The sinter crust on the surface of bones reflects higher precipitation. Thickness $2 \mathrm{~m}$.

Analogy: Layers 2a and 2b Kostnice II, profile ZH P-5.

Zoopaleontological finds: Many bone fragments of Ursus cf. deningeri. Furthermore Panthera fossilis (a great number), Bos or Bison, Sus scrofa.

Layer 3b. Yellow rusty loose sediment without limestone debris. Few bones, mostly small fragments. Loam raddles of a rusty yellow colour.

Layer 3c. Dark-brown clayey silt with limited limestone debris. On debris surface manganese crust, calcareous nodules (concretions), fragments of vein quartz, loam raddles of a brown colour.

Layer 3d. Many horizons of yellow and darker clayey silt, thickness cca $2 \mathrm{~cm}$. Many bones, loam sinters and

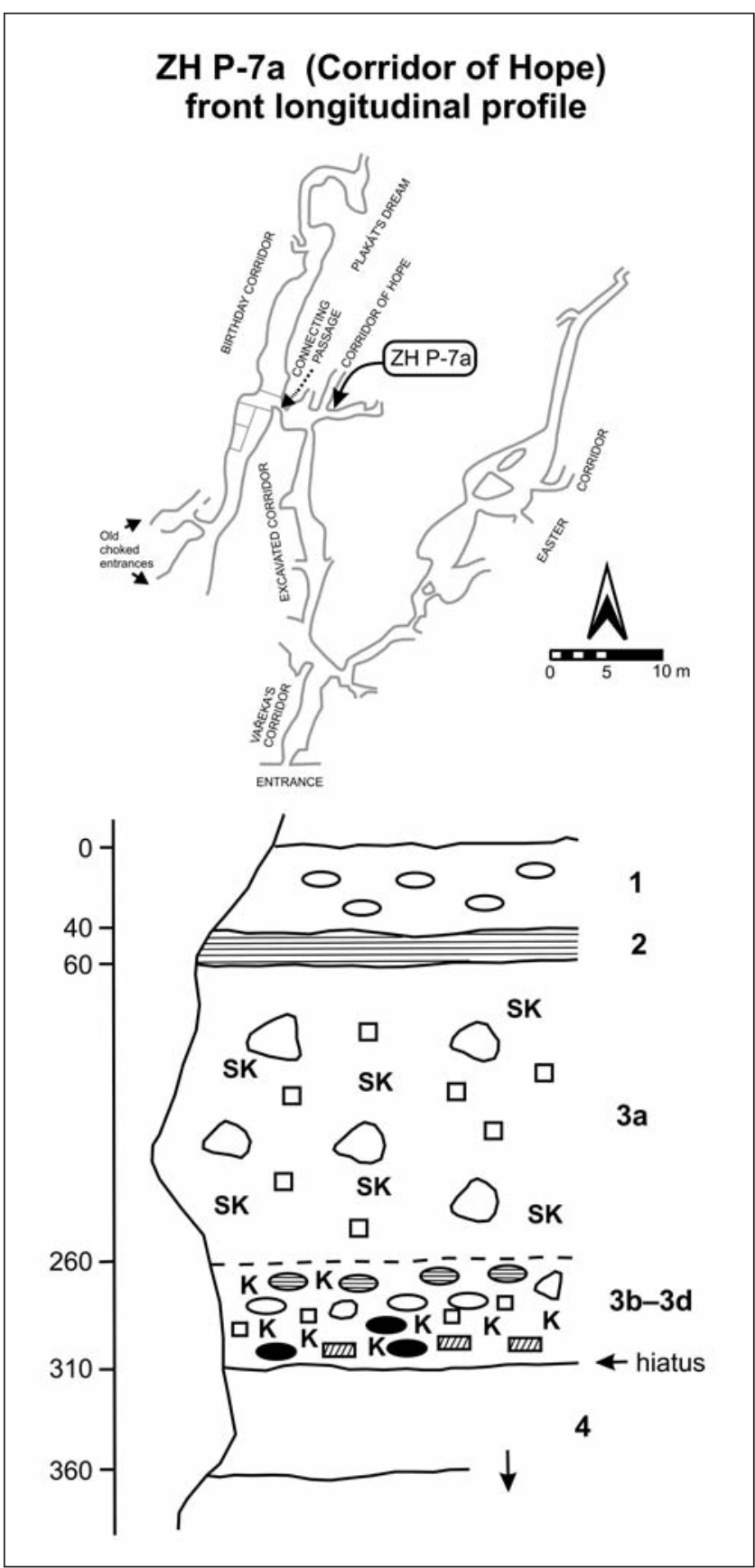

Text-fig. 8. Za Hájovnou Cave. Section ZH P-7a (Chodba naděje (= Corrridor of Hope), front longitudinal profile).

manganese nodules. Towards the base fewer whole bones and more bone splinters.

Total thickness of all horizons in layer 3 is $2.0-2.5 \mathrm{~m}$.

There is a depositional hiatus between the layers $3 \mathrm{~d}$ and 4 .

Layer 4. Fluvial clayey deposits without paleontological finds, the same as in fluvial deposits in Kostnice II. Their base not identified.

Macroscopic analogy: Layers 4-8, profile ZH P-5, Kostnice II.

\section{Profile ZH P-7b}

Back part of the Chodba naděje, a transverse profile (layers 1-6). 


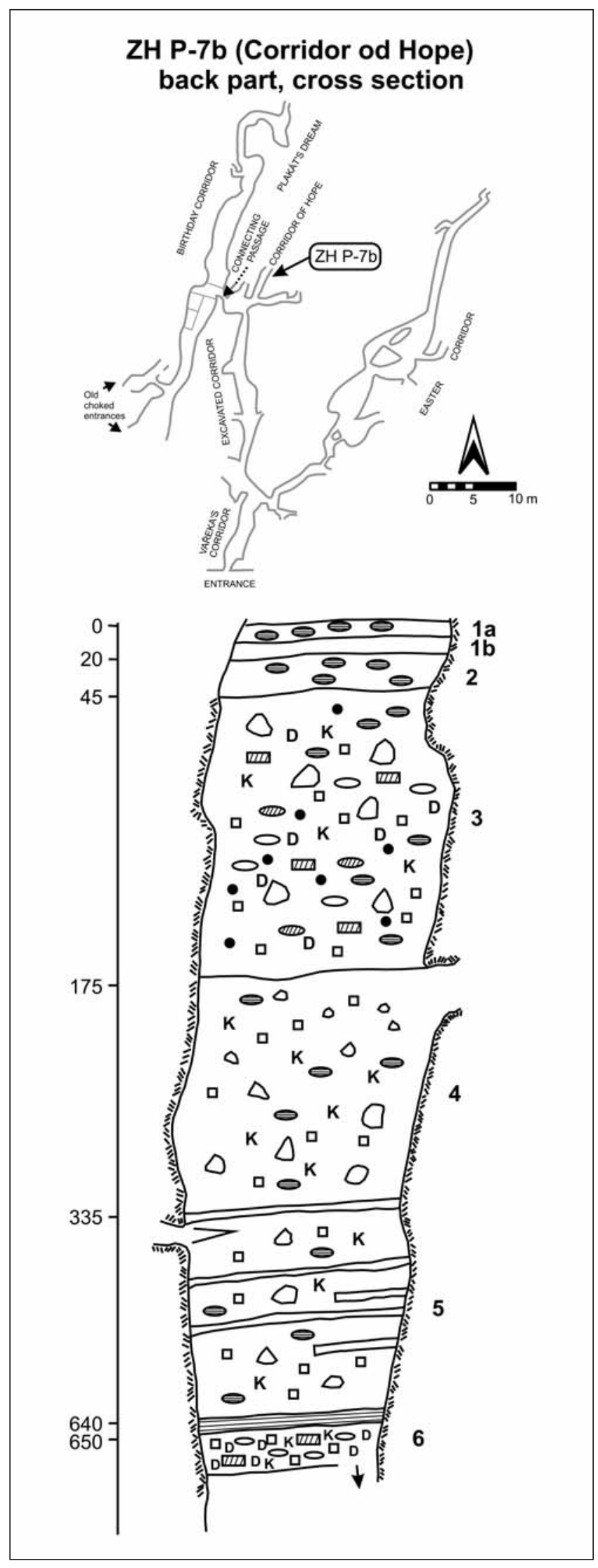

Text-fig. 9. Za Hájovnou Cave. Section ZH P-7b (Chodba naděje (= Corridor of Hope), back part, cross section).

Layer 1a. Dark-brown clayey silt without paleontological finds, only bones of bats (recent), loam raddles of a yellow colour. Without limestone debris.
Layer 1b. Clayey silt of yellow-brown colour, without limestone debris and without paleontological finds. Layers $1 \mathrm{a}$ and $1 \mathrm{~b}$ are distinctly separated.

Layer 2. Brown crumbly clayey silt, loam raddles of brown colour. Thickness $25 \mathrm{~cm}$.

Layer 3. Dark-brown clayey silt of heterogenous colours. Strongly disintegrating limestone debris with manganese crust. Very few bones. Fragments of loam sinter 40 x 20 x $10 \mathrm{~cm}$ in size and from the bottom about half $\mathrm{cm}$ thick sinter. Calcareous nodules, many fragments of vein quartz, pebbles of culm greywackes and slates. Loam raddles of dark- brown or brown colours. Fragment of crystallic stalagmite. Small manganese nodules. Thickness $130 \mathrm{~cm}$.

Zoopaleontological finds: Panthera fossilis.

Layer 4. Brownish-red sometimes rusty clayey silt. More clayey than the overlying layer. Bones scattered throughout the layer thickness. In the upper part small size debris, towards the base larger. Limestone debris are disintegrating and with a manganese crust. Vein quartz, occasional loam raddles of a grey colour. Horizontally freshly separated clayey beds cover the whole profile.

Zoopaleontological finds: Panthera fossilis.

Layer 5. At a depth of 640-650 cm thinly laminated fine clayey earth, thickness $10 \mathrm{~cm}$.

Layer 6. Brownish-yellow clayey silt, calcareous nodules, fragments of cave bottom sinter, vein quartz, many pebbles of culm graywackes and slates. Decreasing number of bones.

Zoopaleontological finds: Panthera fossilis.

\section{Spojovací chodba (= Connecting Passage) between Vykopaná chodba and Narozeninová chodba}

I have dividend this area into two concuring exposures. The first of them (ZH P-8a) lies directly in the Spojovací chodba between the Vykopaná and Narozeninová chodba, the second profil ( $\mathrm{ZH} \mathrm{P}-8 \mathrm{~b}$ ) extends from the first profile and continues to the rock wall of the Narozeninová chodba (Trench A). Both profiles come from transverse sections.

\section{Profile ZH P-8a}

The Spojovací chodba, transverse section (layers 1-3) (Lundberg et al. 2014, ZH P-8/9).

Layer 1. Laminated fine clayey silt penetrating from Kostnice II, without limestone debris and paleontological find (infiltration cave sediment). Thickness $40 \mathrm{~cm}$.

Macroscopic analogy: Layers 1a and 1bof profile ZH P-6, Kostnice I and with layer 1b, Kostnice II profile ZH P-5.

Text-fig. 10

Layers 2a, 2b. Loose brown sediment, limestone debris, loam raddles, many fragments of stalactites, fragments of vein quartz, bones of bears, small manganese nodules. Thickness $90 \mathrm{~cm}$. The layers are connected with Profile $\mathrm{ZH}$ $\mathrm{P}-5$, layers $2 \mathrm{a}$ and $2 \mathrm{~b}$.

Macroscopic analogy: Profile ZH P-5, Kostnice II, layers $2 \mathrm{a}$ and $2 \mathrm{~b}$. 


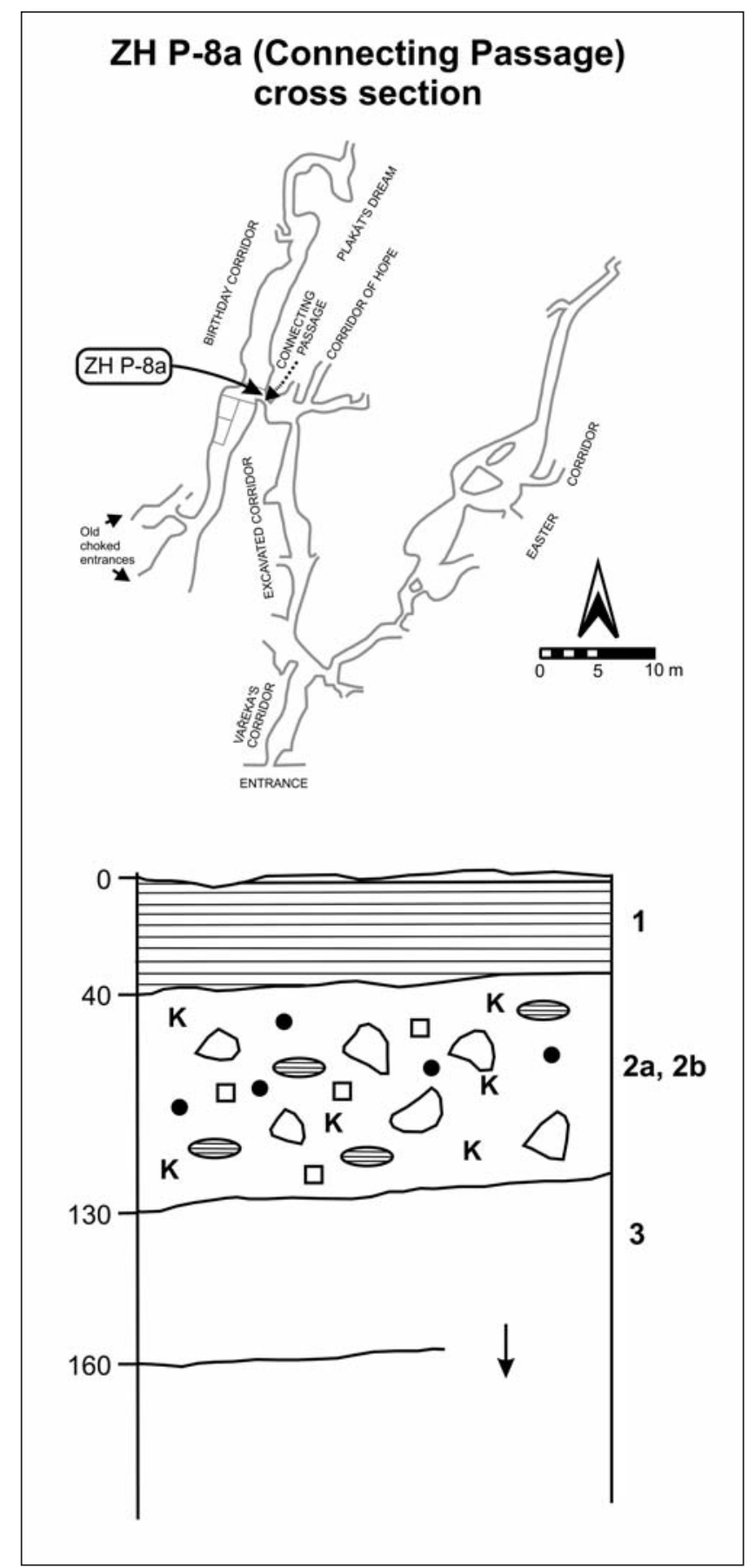

Text-fig. 10. Za Hájovnou Cave. Section ZH P-8a (Spojovací chodba (= Connecting Passsage) between Vykopaná chodba (= Excavated Corridor) and Narozeninová chodba (= Birthday Corridor), cross section).

Layer 3. Brown clayey silt without limestone debris. Base not identified.

Macroscopic analogy: Profile ZH P-5, Kostnice II, layers $3 \mathrm{a}$ and $3 \mathrm{~b}$.

\section{Narozeninová chodba (= Birthday Corridor)}

\section{Profile ZH P-8b}

Transverse section, Trench A (layers 1-4). It is connected with Profile ZH P-8a (Lundberg et al. 2013, ZH P-8/9).

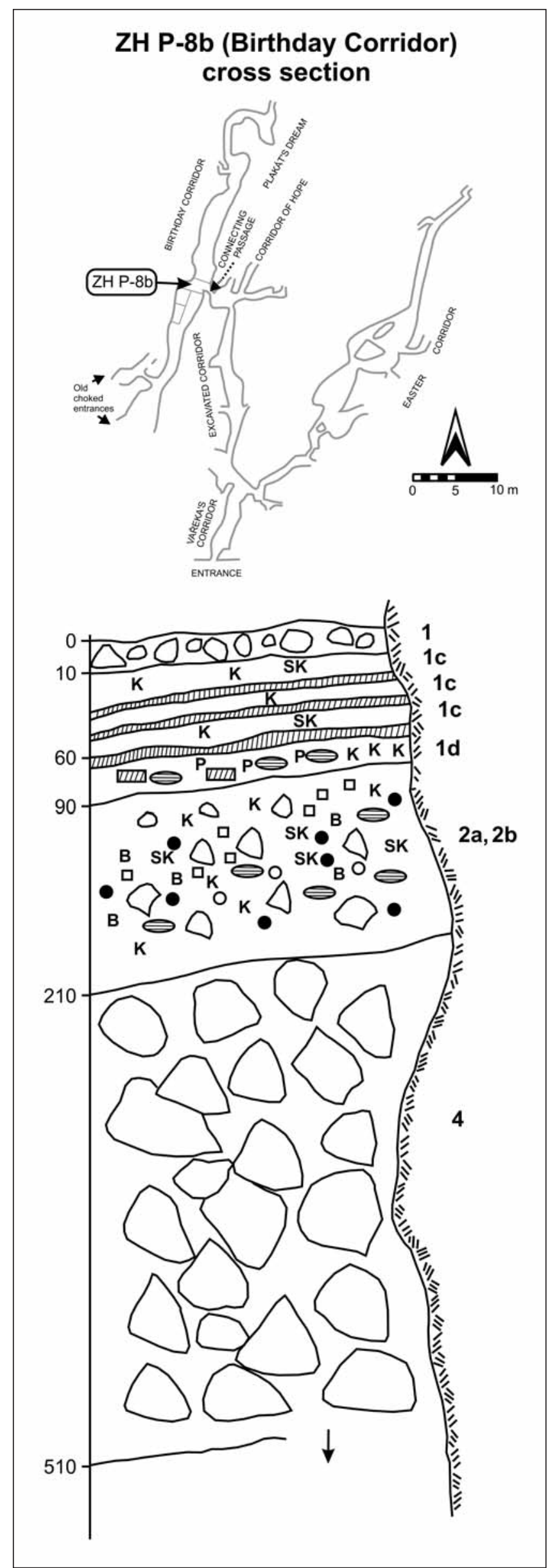

Text-fig. 11. Za Hájovnou Cave. Section ZH P-8b (Narozeninová chodba (= Birthday Corridor), cross section, Trench A). 
Layer 1. Various large size limestone debris, derivable from the supposed entrance of the Narozeninová chodba. Gravitational redeposition of sediments of various ages.

Layer 1c. (Lundberg et al. 2014, layer 1, Profile ZH P-8/9). Many thin layers. Clayey silt of light-brown colour, without limestone debris, few bone fragments, some covered with sinter. In this layer two thin sinter stratulums showing disruption of settling. Fragments of stalactites, straw stalactites and thin sinter. The greatest thickness is near the rock wall, $50 \mathrm{~cm}$, decreasing towards the centre of the corridor.

Zoopaleontological finds: very few bone fragments of Ursus spelaeus. Findings of cave bears suggest that the original entrance to the Narozeninová chodba was still open in the Upper Pleistocene. The following rodents were found: Microtus gregalis, Microtus oeconomus, Microtus arvalis/agrestis group, Microtus aff. coronensis, Clethrionomys glareolus (Ivanov 2005).

Layer 1d. (Lundberg et al. 2014, layer 2, profile ZH $\mathrm{P}-8 / 9)$. The bottom sinter on the surface is ca $5 \mathrm{~cm}$ thick with small vertical stalagmites $15-20 \mathrm{~cm}$ tall, about $10 \mathrm{~cm}$ in width at the base. Loose brown clayey silt, smudges of dark-brown colour. Bones only near rock wall, otherwise absent. At the base two thin layers $(1 \mathrm{~cm})$ of sandy sinter. Weak lamina of broken gastropod shells. Clayey loam raddles in brown colour, fragments of stalactites, straw stalactites, bottom sinter. Thickness $30 \mathrm{~cm}$.

Zoopaleontological finds: very few fragments of bear bones. Gravitational redeposition up to the Holocene, the overlying bottom sinter from the Recent.

Layers 2a, 2b. (Lundberg et al. 2014, layers 3a and 3b, profile ZH P-8/9). Homogenous brown clayey silt, to a depth of $50 \mathrm{~cm}$ small sized limestone debris Lower down the clasts increase in size. Some clasts have black surface. Bone fragments from adult bears and neonates, some with sinter crust or with black surface. The sinter crust on the bone surface reflects greater precipitation. Those on the bottom have disintegrated to dust. Some bones are transversely and lengthways full of cracks, and the fissures are filled with loam. This indicates that the bones lay on the surface for a long time. Many isolated teeth. The number of bones decreases towards the base as well as the number with a sinter crust on the surface. Sporadically bone beds (breccia) occur. Loam sinters are absent. Clayey or loessic loam raddles in rusty red or dark brown colour. In some areas small quartz chesils. More stalactite fragments, straw stalactites, fragments of thin sinter plates, in the upper part vein quartz about 3-4 cm in size and larger manganese nodules.

It was possible to identify the continuation of this layer through the Spojovací chodba with layers $2 \mathrm{a}$ and $2 \mathrm{~b}$ in Kostnice II. Thickness 120-130 cm.

Zoopaleontological finds: Bear bones in the upper part with a sinter crust but without in the lower part. Higher precipitation. Bone fragments of fox or hare, in addition Panthera fossilis, Ursus cf. deningeri, Equus sp. (the lower part of the layer) (Ábelová 2005, Wagner 2005). Herpetofauna from the lower part of the layer Vipera berus. Rodents: Microtus gregalis, Microtus oeconomus, Microtus arvalis/agrestis group, Clethrionomys glareolus, Arvicola terrestris (Ivanov 2014).

Palynological spectrum: A layer with multifarious finds of palynospectra: Alnus, Ulmus, Salix, Fraxinus, Juniperus,
Picea, Pinus sylvestris (dominant), Pinus cembra (Doláková 2014).

Layer 4. Debris cone (Lundberg et al. 2014, layer 4, Profile ZH P-8/9). The bottom of the debris cone contains limestone blocks up to $1 \mathrm{~m}$ in size (80-90\%), between them brown sediment. Minimum thickness $300 \mathrm{~cm}$. The base hasn't been identified. No analogy with exposures in the Vykopaná chodba.

\section{Profile ZH P-9}

Substitute for Propástka 1 and Propástka 2 (Area A, layers 1-6) (Lundberg et al. 2014, ZH P-8/9)

This exposure is directly connected to the previous profile. In this case however the profile is lengthwise orientated. Layers 1 to 4 are in the horizontal part of the corridor, all the others (layers 5 and 6) are in Propástka 1 and 2 .

Layer 1. Brown sediment sporadically loose or clayey, in wet plastic. Without limestone debris, occasional bones, fragments of straw stalactites, sinter plates, stalactites, loam sinter. Thickness $50 \mathrm{~cm}$. Gravitational redeposition up to the Holocene.

Zoopaleontological finds: Sporadic bear bone fragments (Ursus sp.) with sinter crust.

Layer 2. Brown clayey sediment in wet plastic, small amount of limestone debris. On the surface sinter crust. Fragments of sinter plates, straw stalactites, loam raddles. Value of magnetic susceptibility: 0.93-1.04, average from eight measurements 1.02 . Thickness $40 \mathrm{~cm}$.

Zoopaleontological finds: Very few bone fragments but several gastropod shells. Ursus spelaeus. Repeated gravitational redeposition of older sediments (Last Glacial and older) up to the Holocene.

Layer 3. (Lundberg et al. 2014), layer 3a, 3b, Profile ZH $\mathrm{P}-8 / 9$, the layer is the same as ZH P-8a and 8b, layer 2a, 2b). Brown clayey silt with large debris of varying size. Relatively few bear bones, sometimes highly disintegrated, with black surface, occasionally with sinter coating, sometimes bonded to debris. The sinter crust on the surface of bones reflects significant precipitation. Fragments of sinter plates, vein quartz (the largest being $15 \times 20 \mathrm{~cm}$ ), loam raddles in dark-brown colour, fragments of stalactites, quartz chesils, pebbles of culm graywackes and slates. Value of magnetic susceptibility: 1.30-1.68, average from nine measurements 1.28. Thickness $130 \mathrm{~cm}$.

Macroscopic analogy: The layer matches layers $2 \mathrm{a}$ and 2b, Kostnice II, profile ZH P-5.

Zoopaleontological finds: In upper part bear bones with black (manganese) surface and with sinter coating. Significant precipitation. In lower areas without sinter crust and disintegrating. Smaller bone probably from fox. Ursus cf. deningeri, Panthera fossilis.

Layer 4. Large limestone blocks (70\%), in gaps brown sediment. Mostly without bones, if present, then with black surface or cemented with sinter to debris. Bone beds (breccia), sporadically vein quartz and fragments of stalactites. Value of magnetic susceptibility: 0.45-0.92, average from five measurements 0.73 . The talus cone 


\section{ZH P-9 (Birthday Corridor) Area A, Abyss I and II}
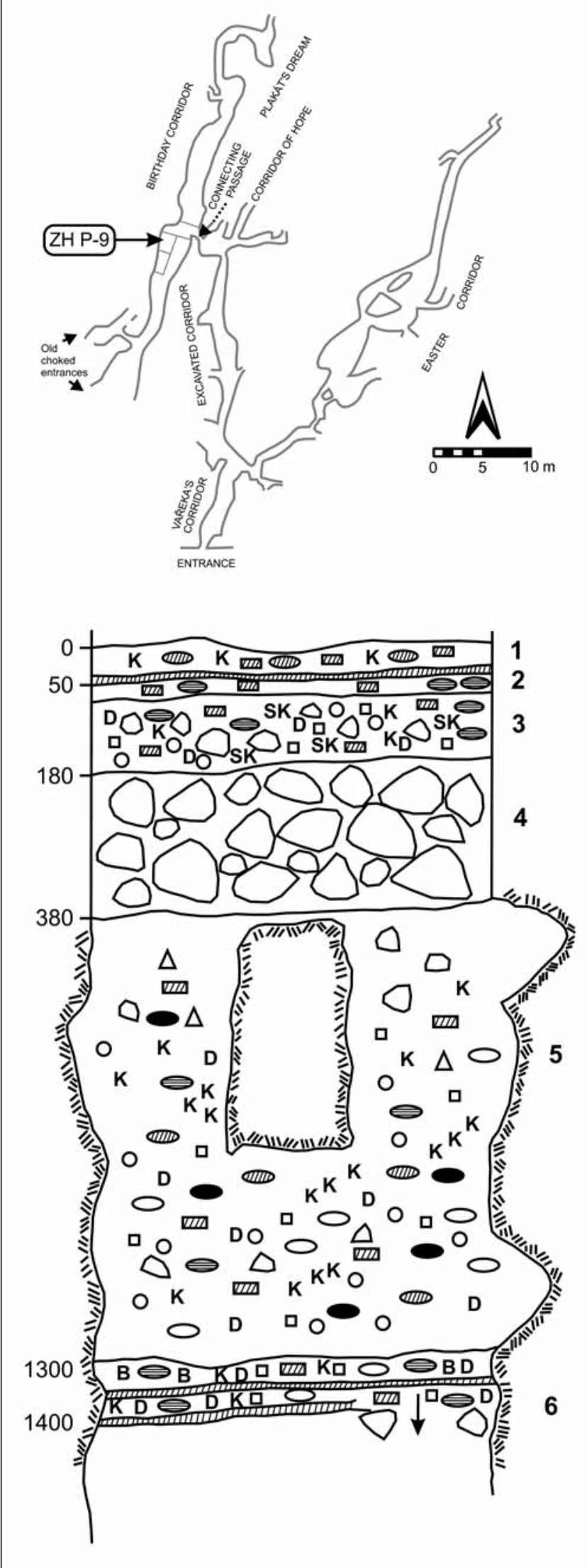

Text-fig. 12. Za Hájovnou Cave. Section ZH P-9 (Narozeninová chodba (= Birthday Corridor), Area A, Propástka 1 and 2 (= Abyss I and II)). continues along the length of the Narozeninová chodba. Exposed thickness herein $200 \mathrm{~cm}$.

The talus cone has no analogy with sections in the Vykopaná chodba or in the Chodba naděje.

Palynological spectrum (lower part of layer 4): A layer with multifarious finds of palynospectra: Carpinus, Tilia, Betula, Corylus (dominant), Juniperus, Pinus sylvestris, Pinus cembra (Doláková 2014).

Layer 5. This layer occurs under the rock wall and at the beginning divides into two parts (Propástka 1 and Propástka 2). Sediments in the upper part of both abysses are somewhat different.

Detail: In the left part of Propástka 2 the clayey silt is of a different shade of brown colour with solitary limestone debris. Layer 5a (value of magnetic susceptibility: 1.01-1.54, average from ten measurements 1.24), layer 5b1, $5 \mathrm{~b} 2$ (value of magnetic susceptibility: 0.65-1.03, average from ten measurements 0.69 ). In the underlyiing layer ochre coloured sediment, layer $5 \mathrm{c}$ (value of magnetic susceptibility: 0.22-0.42, average from ten measurements 0.35 ). Under this layer russet red laminated clay (value of magnetic susceptibility 1.03-1.94, average from ten measurements 1.45). In the underlying bed relict of red clay (value of magnetic susceptibility: $0.63-0.95$, average from ten measurements $0.73)$.

Detail: In the right part of Propástka 2 several layers of brown clayey silt. Layer 5a (value of magnetic susceptibility $0.25-0.76$, average from ten measurements 0.50 ). Between the layers $5 \mathrm{a}$ and $5 \mathrm{~b}$ is rusty clay (value of magnetic susceptibility 1.01-1.54, average from ten measurements 1.24). In underlying bed some layers of brown laminated clay. Layer $5 \mathrm{c} 1$ (value of magnetic susceptibility: 0.44-0.69, average from ten measurements 0.59 ), layer $5 \mathrm{c} 2$ (value of magnetic susceptibility: $0.65-1.03$, average from ten measurements 0.69 ), value 5c3 (value of magnetic susceptibility: 1.03-1.94, average from ten measurements 1.45). Between these layers $\left(5 \mathrm{c}_{1}\right.$ and $\left.5 \mathrm{c}_{2}\right)$ light-brown laminated clay with small sized debris $(5 \mathrm{~d})$, with bones, different in colour from layer $5 \mathrm{a}$ (value of magnetic susceptibility $0.20-0.61$, average from ten measurements 0.43) (all measurement of magnetic susceptibility and drawings by E. Pavelová).

Generalized description of layer 5. Loose brown clayey silt, some dark-brown, mostly without debris. Fragments of thin sinter plates $(1 \mathrm{~cm})$, fragments of stalagmites (length $10 \mathrm{~cm})$, much loam sinter and vein quartz (size 5-7 cm), pebbles of culm slate, calcareous nodules, larger manganese nodules and manganese crusts up to half $\mathrm{cm}$ thick, quartz chesils, fragments of bottom crystallic sinter about $10 \mathrm{~cm}$ thick, clayey or loessic raddles of rusty colour. On limestone debris manganese crusts. At a depth of $5 \mathrm{~m}$ occasional small sized limestone debris.

Bones not regularly scattered, mostly in clusters, some in anatomical position. In lower $4 \mathrm{~m}$ of the middle section, many bones of bear neonates. Microfauna. Thickness $9 \mathrm{~m}$.

Layer 5 does not originate from one climatic period, as the palynological analysis indicates, probably however from very warm climates. At present it is not possible to divide the layer into sub layers.

Palynological spectrum: The samples for palynolological analysis were taken throughout the thickness of this layer. From the top of this layer to the bottom: 


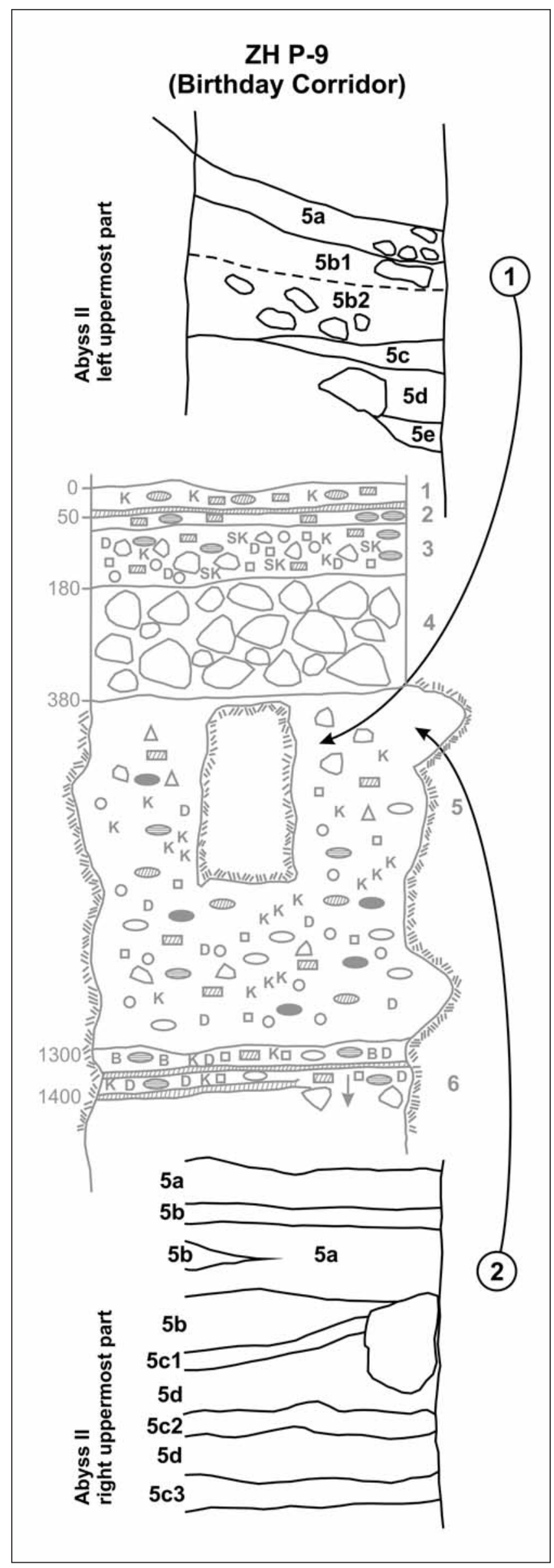

Text-fig. 13. Za Hájovnou Cave. Section ZH P-9 (Narozeninová chodba (= Birthday Corridor), Area A, detail of the upper part of Propástka 2 (= Abyss II)).
0.2 m: Carpinus, Tilia, Betula, Corylus (dominant), Sambucus, Picea, Pinus sylvestris, Pinus cembra, herbs.

1.2-1.5 m: Alnus, Ulmus, Salix, Fraxinus, Corylus (dominant), Picea, Pinus sylvestris, Pinus cembra, herbs.

2-2.3 m: Carpinus, Tilia, Alnus, Ulmus, Salix, Fraxinus, Betula, Corylus, Picea, Pinus sylvestris (dominant), Pinus cembra, herbs.

3 m: Carpinus, Tilia, Alnus, Ulmus, Salix, Fraxinus, Betula, Corylus (dominant), Picea, Pinus sylvestris (dominant), Pinus cembra, herbs.

5-6 m: without finds

6.5-7.5 m: Corylus, Picea, Pinus sylvestris (dominant), Pinus cembra, herbs (Doláková 2014).

Paleozoological finds: Whole bones in anatomical position of adult and juvenile bears (neonates) (Ursus deningeri), Panthera fossilis.

Layer 6. At a depth of about 8-9 m several continuous sinter layers about $1 \mathrm{~cm}$ thick. Brown loose sediment similar to the overlying layer with inserts of rusty clay. Continuing to a depth of 9-7 m. The whole thickness of clayey inserts is about $60 \mathrm{~cm}$. These inserts are distinctly separated from the brown sediment. Some sinter fragments, many loam sinters, fragments of vein quartz, pebbles of culm greywackes and calcareous nodules. Fragments and whole bones of bears and lions. Bone beds (breccia). The layer continues more deeply with some larger limestone blocks. Exposed thickness $100 \mathrm{~cm}$, the base wasn't identified.

Palynological spectrum: 8-9 m: Carpinus, Tilia, Quercus, Acer, Corylus, Picea, Pinus sylvestris (dominant), Pinus cembra, herbs.

9.5-10 m: Carpinus, Tilia, Quercus, Acer, Alnus, Ulmus, Salix, Fraxinus, Juglans, Betula, Corylus (dominant), Picea, Pinus sylvestris, Pinus cembra, herbs (Doláková 2014).

Zoopaleontological finds: Very well preserved bones of bears and lions without sinter crust.

\section{Profile ZH P-10}

Between the original entrance of the Narozeninová chodba and Area A/B (layers 1-4). Origin of erosion rill after the development of layer 3 and before the origin of cave bottom sinter (239 ka).

Layer 1. Loose brown clayey silt, very little limestone debris, loam sinter. On the surface cave bottom sinter (thickness $1 \mathrm{~cm}$ ). Towards the original entrance the layer divides into two parts separated by $10 \mathrm{~cm}$ thick cave bottom sinter. Gravitational redeposition of older sediments to the Holocene, the sinter plate from the Recent.

Palynological spectrum: A small number of pollen grains from Pinus and some herbs.

Layer 2. (Lundberg et al. 2014, layers 2a, 2b). Light brown loose clayey silt, without limestone debris (gravitational redeposition). Palynologically sterile.

There is a depositional hiatus between the layer 2 and cave bottom sinter.

Cave bottom sinter. $10 \mathrm{~cm}$ thick, with no visible hiatus, lying on the side of the erosion rill, overlying layer 3. The base $239 \pm 4 \mathrm{ka}$ (MIS 7-8). The upper part $178 \pm 1 \mathrm{ka}$ (MIS 6) represents the colder early stage of MIS 6. (Lundberg et al. 2014, flowstone layer). 


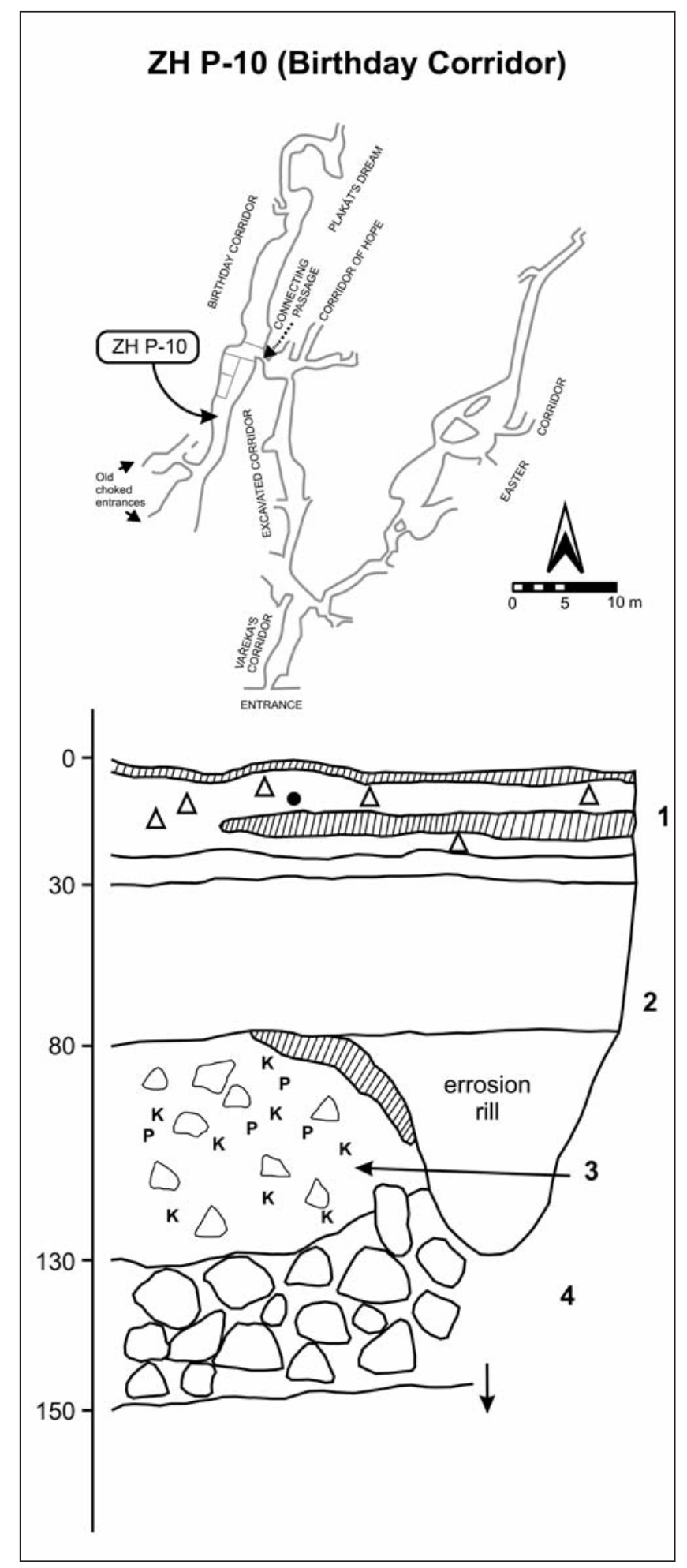

Text-fig. 14. Za Hájovnou Cave. Section ZH P-10 (Narozeninová chodba (= Birthday Corridor), erosion rill).

Layer 3. (Lundberg et al. 2014, layer 3a, 3b). Brown clayey silt with limestone debris, bone fragments often cemented by sinter to clasts. The sinter crust on the bone surfaces reflects significant precipitation. Small fragments of undefinable gastropod shells.

Macroscopic analogy: Kostnice II, ZH P-5 (layers 2a and 2), ZH P-8a and ZH P-8b (layers 2a, 2b), ZH P-9 (layer 3).

Zoopaleontological finds: Frequent bone breccia. Undeterminable fragments of gastropod shells.
Layer 4. Large limestone blocks (80\%), between them brown sediment and fragments of bones. The base of the debris cone wasn't identified.

Palynological spectrum (upper part of layer 4): A layer with multifarious finds of palynospectra: Juglans, Betula, Abies, Picea, Pinus syvestris (dominant), Pinus cembra, herbs (Doláková 2014). The structure is similar to ZH P-5 (layers $2 \mathrm{a}$ and 2b), ZH P-8b (layers $2 \mathrm{a}$ and 2b), ZH P-9 (layer 3), ZH P-11 (layer 4).

\section{Profile ZH P-11}

The location of the original entrance to the Narozeninová chodba, filled with limestone debris, under the chimney (layers 1-5)

Layer 1. Middle-sized debris from the entrance, loessic brown loam. Without fossil remains, fragments of thin sinter plates. Thickness $15 \mathrm{~cm}$.

Bottom sinter, thickness $12 \mathrm{~cm}$. U/Th dating: The base $118 \pm 1 \mathrm{ka}$, (MIS 5e).

Layer 2. Brown clayey silt, small limestone debris, loam sinter, vein quartz. Older allochthonous deposits (probably Eemian). Thickness $10 \mathrm{~cm}$.

Paleozoological find: Well preserved Helix shell.

Discontinuous bottom sinter. Thickness $10-15 \mathrm{~cm}$.

There is a depositional hiatus between the discontinuous bottom sinter and layer $3 \mathrm{a}$.

Layer 3a. Red-brown clayey silt, thin dark layers, $2-3 \mathrm{~cm}$ thick. Small amount of limestone debris, loam sinter, in upper part vein quartz and thin sinter layers. A small quantity of bear bones. Thickness $60 \mathrm{~cm}$.

Layer 3b. Dark-brown clayey silt, fragments of brown sinter, loam sinters, manganese crust, vein quartz, only a few bones in the upper part, more in the lower part, mostly bear ribs. Also a bear skull. Some bones with a sinter crust. The sinter crust on the bone surfaces reflects significant precipitation. Small sized limestone debris, 5-10 cm only. Value of magnetic susceptibility: $0.67-1.12$, average from eleven measurements 0.8336 .

Zoopaleontological finds: Few bear bones, bone fragment of lizard or roebuck. The layers are reminiscent of Kostnice II, ZH P-5 (layers 2a and 2b), ZH P-8a and ZH P-8b (layers $2 \mathrm{a}$ and $2 \mathrm{~b}$ ), ZH P-9 layer 3).

Layer 4. Large limestone blocks (talus cone). Thickness at least $30 \mathrm{~cm}$, the base wasn't identified. Value of magnetic susceptibility: $0.25-0.30$.

Palynological spectrum (upper part of layer 4): A layer with multifarious finds of palynospectra: Juglans, Betula, Abies, Picea, Pinus sylvestris (dominant), Pinus cembra and herbs (Doláková 2014). The structure is similar to ZH P-5 (layers $2 \mathrm{a}$ and $2 \mathrm{~b}$ ), $\mathrm{ZH} \mathrm{P}-8 \mathrm{a}$ and $8 \mathrm{~b}$ (layers $2 \mathrm{a}$ and $2 \mathrm{~b}$ ), $\mathrm{ZH}$ P-9 (layer 3), ZH P-10 (layer 4).

\section{Sedimentary components and stratigraphy}

Several recurring types of sediments were present in the cave. Almost all of the layers contain limestone debris of different dimensions. Sometimes its surface was covered by a thin sinter crust. Fragments of cave bottom sinters and relatively many fragments of sinter crust of various sizes and 


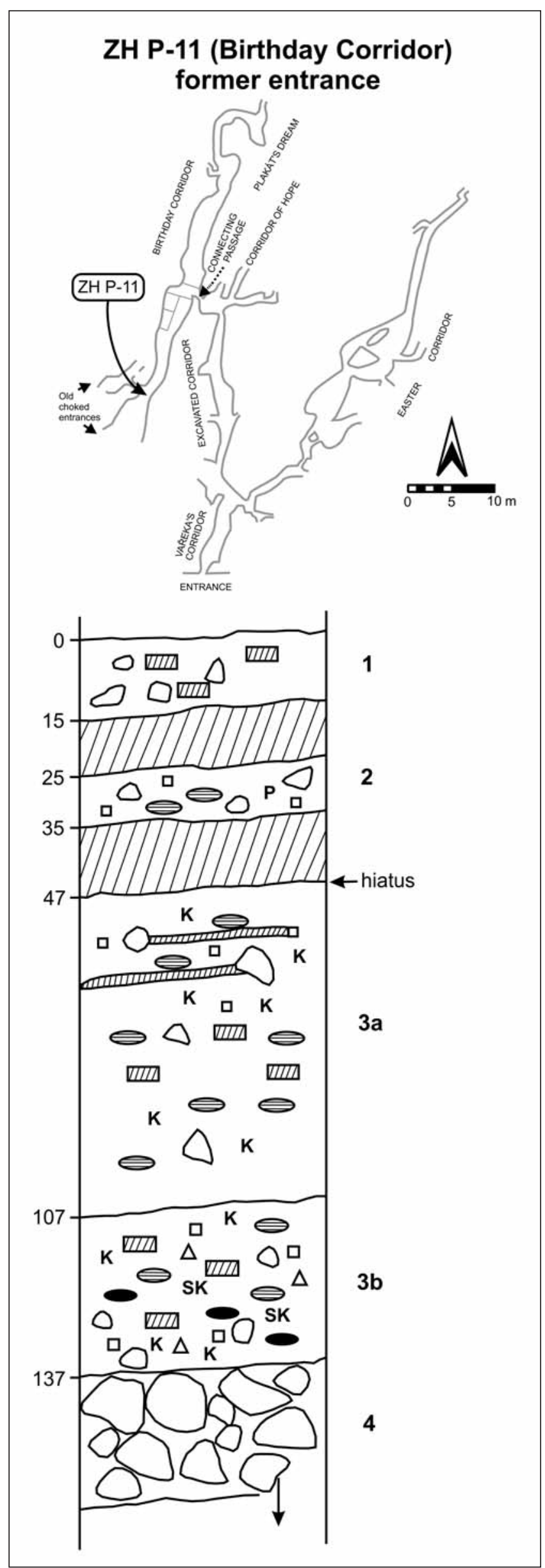

Text-fig. 15. Za Hájovnou Cave. Section ZH P-11 (Narozeninová chodba (= Birthday Corridor), former entrance). thickness were present. Only in certain exposures and only in some layers were there fragments of needle calcite crystalline aggregates. In some layers there was typical loam sinter (loam with a high content of $\mathrm{CaCO}_{3}$ ) which had formed various large sized hard agglutinates (clusters), usually of grey colour. In some sediments I found calcareous nodules, quite similar to loessic nodules, some hollow, others solid. Vein quartz of different sizes and shape were abundant. Quartz found as chesils was in the form of marble. In almost all layers there were oval raddles (fine-grained loam with thin lamination of various colours) with a diameter around $5 \mathrm{~cm}$. We found large manganese nodules (concretions of oxides and hydroxides), dark or black colour, about $2-3 \mathrm{~cm}$ in size and small $\mathrm{Mg}$ or Fe nodules (concretions) of black colour, about $1 \mathrm{~mm}$ in size. Disintegrating pebbles of culm greywackes or slates, mostly of nut size were sporadically found.

Deposits in many cave corridors have usually an identical composition for the entire length. Macroscopically it is always the same layer. This is not the case however in $\mathrm{Za}$ Hájovnou Cave. The separate exposures of corridors reflect in superposition of different layers.

The deposit sequence in the Vykopaná chodba and from the Narozeninová chodba are different. For stratigraphic classification of the layers in the Narozeninová chodba it is very important that the layers $2 \mathrm{a}$ and $2 \mathrm{~b}$ from Kostnice II (profile ZH P-5, dated $267 \pm 3 \mathrm{ka}$ ) continued through the Spojovací chodba (ZH P-8a) between the Vykopaná chodba and further into the Narozeninová chodba to profiles ZH P-8b and ZH P-9. All the underlying layers starting with the debris cone (layer 4), which stretches the entire length of the Narozeninová chodba, are therefore earlier than ZH P-5 layers $2 \mathrm{a}$ and $2 \mathrm{~b}$. The debris cone is a few meters thick, and on the base there are large boulders. Similar debris cones known from other localities usually reflect the start of a warm period (Musil 1995a, b).

\section{Sedimentary facies}

In the cave there are several main types of macroscopically distinguishable layers of sediment.

Group 1. A yellow-brown loess loam with calcareous nodules, the loess originated from the Last Glacial. In the roof there are large blocks of limestone. Loess is a product of a cold arid climate. It is found only in one place, the $\mathrm{ZH}$ P-1 complex IV (upper part of Komín I, Vykopaná chodba). The loessic loam layers there alternate with a large amount of small sharp edged debris (layers 2 and 4) and also with layers of medium rounded limestone debris. Small sharp double-edged debris formed in a period of extremely cool climate. At that time a vertical cave chimney was open to the surface.

This group includes the following sections: Excavated Corridor, ZHP 1, layers 2,3,4,5, Birthday Corridor ZHP 11, layer 1 .

Group 2. Layers of clayey silt of mainly shades of brown and of loessic loam. On the basis of their different content they can be divided into two completely different groups A (A1 and A2) and B, which clearly document different time origins of different environment.

$\mathrm{A}^{1}$. Clayey silt with chaotic located limestone debris of various sizes (up to $50 \mathrm{~cm}$ on average), with significant 
corrosion. The limestone debris are frequently strongly disintegrated and with a manganese crust on the surface, crushable by hand. Frequent subangular fragments of vein quartz (up to $5 \times 10 \mathrm{~cm}$ in size) and small quartz pebbles (average 1-2 cm). Fragments of loam sinters, crystalline sinters and needle calcite crystalline aggregates, fragments of crystaline stalagmites, stalactites fragments, straw stalactites and fragments of thin sinter plates. Both large and small manganese nodules (oxides and hydroxides) on average about $2 \mathrm{~mm}$ in diameter. Loam sinters and bone beds (breccia). The loam sinters are extremely hard, and in the case of larger specimens it was necessary to break them with a pneumatic hammer. Loam raddles of a brick red colour, up to $5 \mathrm{~cm}$ in size were also present. All the bones are preserved in fragments only, whole bones are totally missing. The bones were often completely desintegrated and well preserved are only teeth in the majority of cases. However their roots were often also disaggregated. Oval pieces of spongiosis $2-3 \mathrm{~cm}$ on average were present. On the surface of some bones was a mostly brown coloured sinter crust $1-2 \mathrm{~mm}$ thick. It looked like sand with $\mathrm{CaCO}_{3}$. There were a small number of bones without sinter on the surface. Some bones were transversely and lengthways full of cracks, the fissures were filled with loam. This indicates that the bones lay on the surface for an extended period of time. The bone surface is black. It was therefore probably a period with high torrential rains. Loamy sediments of this group (A) are quite different from the second group (B).

This group includes the following sections: Excavated Corridor, ZHP 5, layers 2a, 2b, Connecting Passage, ZHP 8a, layers 2a, 2b, Birthday Corridor, ZHP 8b, layers 2a, 2b, ZHP 9, layer 3, ZHP 10, layer 3.

$\mathrm{A}^{2}$. Sienna loessic loam from the Middle Pleistocene. It has been found in two sections only, in ZHP 3, layer 5 and ZHP 6, layer 2 (Excavation Corridor). It probably documents colder climate. Occasional limestone gravels. Fragments of vein quartz. A great number of calcareous nodules different in lengthwise form, with proportions about $15 \times 10 \times 20 \mathrm{~mm}$ or larger. A smaller quantity of bone beds (breccia). The surface of the bones is mostly coated with sinter. The sinter crust on the bones shows that they lay on the surface of the sediments for some considerable time.

This group includes the following sections: Excavated Corridor, ZHP 3, layer 5, ZHP 6, layer 2.

Layers were created during recurrent torrential rainfalls. The surface of the hill was without trees and mostly without shrubs, covered only with grass. This also corresponds to the characteristics of the microfauna (Ivanov 2014) and plant association (Doláková 2014).

B. Loose brown clayey silt, occasionally dark-brown, mostly without debris. If debris is present, then only large limestone boulders. Fragments of thin sinter plates $(1 \mathrm{~cm})$, fragments of stalagmites (longitude $10 \mathrm{~cm}$ ), many loam sinters, much vein quartz (size 5-7 cm), sporadic pebbles of culm slate, calcareous nodules, larger manganese nodules and manganese crusts up to half $\mathrm{cm}$ thick, quartz chesils, fragments of bottom crystallic sinter about $10 \mathrm{~cm}$ thick, clayey or loessic raddles of rusty colour. Bones are always complete and unbroken, not regularly scattered, but in clusters, some in anatomical position. They are very well preserved, their surface is smooth, yellowish brown in colour and in no cases weathered.
This group includes the following sections: Birthday Corridor, ZHP 5, layers 5 and 6.

The two groups (A and B) differ substantially in the amount and size of limestone debris. Another big difference is the preservation of bones. In group B they are never weathered. While in group A, the bones are invariably fragmentary, in group B they are nearly always complete, and often even in their anatomical position. This leads us to the conclusion that the bone fragments in the group A are formed through limestone clasts falling on the sediment surface from the cave chimneys .

Group 3. This group represents sediments of the debris cone. The bottom of debris cone is formed almost exclusively by limestone boulders up to $1 \mathrm{~m}$ in diameter. The space between limestone clasts is only sporadically filled with loamy silt of brownish colour. The thickness is $\sim 2 \mathrm{~m}$ or more.

This group includes the following sections: Birthday Corridor, ZHP 8b, layer 4, ZHP 9, layer 4, ZHP 10, layer 4, ZHP 11, layer 4.

Group 4. Clayey to fine grain sandy fluvial sediment of rusty-brown to brown colour. Almost without limestone debris. They were highly disintegrated and had a manganese crust on the surface. Disintegrated pebbles of culm greywackes and slates, fragments of vein quartz, without paleontological finds.

This group includes the following sections: Excavated Corridor, ZHP 5, layers 4 (Brunhes/Matuyama boundary), 5,6,7,8, Corridor of Hope, ZHP 7a, layer 4.

Group 5. A special group (infiltration cave sediment) which occurs only in the overlying layers in karstic chimneys. Thinly laminated loamy deposits, sometimes of double colours, darker brown and brick red, always without limestone debris. Sporadically fragments of needle calcite crystalline aggregates. They evidently indicate slow and repetitive cyclic accumulation. They could be formed only in the rainy seasons when leaking water flooded out fine sediments from the chimney. We find this sediment not only as a layer but in smaller fragments of about $5 \mathrm{~mm}$ in size, common in the layers of group A also. They apparently originated at different times and if they are in fragments in other layers, they originated from the chimney.

This group includes the following sections: Excavated Corridor, ZHP 3, layer 1, ZHP 5, layers 1a, 1b, Corridor of Hope, ZHP 6,layer 2, Connecting Passage, ZHP 8a, layer 1.

\section{Layers correlation}

On the basis of the characteristics of of all the profile layers, it is possible to create groups of layers which probably underwent the same development. It is more than likely that they arose in the same or a very similar climate.

Profile ZH P-2, Complex II, layer 6. This layer is slightly similar to profile $\mathrm{ZH} \mathrm{P}-5$, layers $2 \mathrm{a}$ and $2 \mathrm{~b}$.

Profile ZH P-3, layer 5. The sediment is similar to the Vykopaná chodba, Kostnice I, profile ZH P-6, layer 2.

Profile ZH P-6, layer 2. The sediment is similar to layer 4 (Profile ZH P-3, relict 12-11, Vykopaná chodba) and to layer 5, ZH P-9 (Narozeninová chodba, Propástka 1 and 2).

Only in exposures ZH P-5 and ZH P-6 were many fragments of needle calcite crystalline aggregates as well as a large number of quartz chesils. 
Profile ZH P-7a, layer 4. Fluvial clayey deposits without paleontological finds, the same as the fluvial deposits in Profile ZH P-5, Kostnice II, Layers 4-8.

Profile $\mathrm{ZH} \mathrm{P-8b}$, layers $2 \mathrm{a}$ and $2 \mathrm{~b}$. It was possible to identify the continuity of these layers through the Spojovací chodba with layers $2 \mathrm{a}$ and $2 \mathrm{~b}$ in Kostnice II, Profile ZH P-5.

Profile ZH P-9, layer 3. The layer matches with layers 2a and 2b, Kostnice II, Profile ZH P-5.

Thinly laminated loamy deposits:

Profile ZH P-3, layers 1 and 4.

Profile ZH P-5, layer 1a. Fine clayey thinly laminated deposit of light-brown colour (thickness of lamina 1-3 mm)

Profile ZH P-5, layer 1b. Clayey laminated deposit of dark-brown colour.

Profile ZH P-7a, layer 2. Thinly laminated fine sandy sediment with alternated stratulums of yellow and brown colour. Analogy with Profile ZH P-5, Kostnice II, layer $1 \mathrm{~b}$.

Profile ZH P-8a, Spojovaí chodba, layer 1. Laminated deposit penetrating from Kostnice II, without limestone debris or paleontological finds. Macroscopic analogy with layers $1 \mathrm{a}$ and $1 \mathrm{~b}$, Profile ZH P-6, Kostnice I and with layer 1b, Kostnice II profile ZH P-5.

\section{Discussion and stratigraphic sequence}

\section{Stratigraphic interpretation based on the preservation of bones}

For interpretation of the former environment, an important role is played not only by the community of plants and animals, but also the preservational state of osteological material.

Considering the bones found in this site we can distinguish in the group 2 two different sedimen s and bone preservation (see the chapter on sedimentary facies). The sediments of both groups are brown to dark brown in colour which distinguishes the bones from the various layers. In this case, we are mainly interested in the layers of group 3

Group $2 \mathbf{A}^{\mathbf{1}}$. All bones without exception are in fragments and mostly with strong corrosion. Their surfaces (as well as the spongiosa) are mostly black (manganese) encrusted with several millimeter thick sinter. This was created after the bones were broken. Occasionally we found disintegrated bones. In layers with such finds bone beds (bone breccia) are common with a minimum quantity of loam (only bone fragments and debris) of various sizes. Loam sinters without debris form various sized large hard agglutinates. Fragments of flowstones, dripstones, vein quartz, quartz pebbles, manganese nodules and fine grained raddles of various colour are also common.

All the above mentioned signs indicate an unstable environment, probably with significant rainfall. The sinter crust on the surface of bones, disintegrated bones and loam sinters indicated a time of greater precipitation. All the fragments of cave bottom sinters, dripstonesand probably the fine grained loam raddles come from chimneys. At this time destruction of chimney decoration occurred. The activity of the water caused limestone debris in the chimneys to break off and stones of various sizes fell onto the loam surface breaking the bones. Under conditions of continuous water supply from the chimneys formation of a stable permanent surface was not possible. The addition of debris also prevented this. Therefore a bottom sinter could not be created, but only loam sinters, bone beds and a sinter crust on bone fragments.

Group $2 \mathbf{A}^{2}$. The composition of the sediments is similar to group $2 \mathrm{~A}^{1}$ differ by the presence of loessic loam..

Group 2 B. The sedimentary sequence in the Narozeninová chodba is different from that in the Vykopaná chodba. Along the entire length of this corridor a huge debris cone extends. Layers from ZH P-5 (layers $2 \mathrm{a}$ and $2 \mathrm{~b}$ ) penetrate into the Spojovací chodba over the debris cone. In the underlying bed of the debris cone there are deposits of brown colour (group B), with a thickness up to $10 \mathrm{~m}$. Sediments are substantially different from those in group A. They are free of limestone debris, only sporadic larger boulders. The osteological material is preserved in a completely different way. The bones are mostly complete, their surface is smooth, coloured, without sinter crust. Traces of weathering are not visible. From palynological study an interglacial period climatically different from that when the the sediments of group A were deposited may be suggested.

\section{Stratigraphic evaluation on the basis of sediment}

This chapter is focussed only on the sediments and their inorganic content. Only the fluvial sediments in the Vykopaná chodba and the debris cone in the Narozeninová chodba entered the cave through the entrance. All other material was deposited via karst chimney waters from the surface.

The oldest layer within the fluvial sediments is found only in the Vykopaná chodba (ZH P-5 layers 4, 5-8 and ZH P-7a, layer 4). In the upper part lies the paleomagnetic boundary B/M (MIS 19) (Kadlec et al. 2005, 2014). The greater part of the sediments comes from the Early Pleistocene and the upper part extends into the Cromerian Interglacial Complex. At this time (780 $000 \mathrm{BP})$, the valley bottom was about 20 $\mathrm{m}$ higher than the present stream.

Čatloš and Fejdi (2005) found that all the minerals found in the fluvial sediment originated from the upper part of the river Špraněk reception basin. This river does not now flow in the direction towards Za Hájovnou Cave (Text-fig. 2). At the present time it flows in the valley below the cave, as the Javoříčka stream, a tributary of the Špraněk. The stream pattern had been transformed from the Early Pleistocene, as previously suggested by Panoš (1964) and Panoš et al. (1998) later reported on the basis of other supporting documents.

We found the previously mentioned minerals not only in fluvial sediment, but also in many layers in the cave. This indicates that their transport on the slopes above the cave happened before the formation of the ponor, or that the valley was filled with Baden marine sediments (Musil 2005a). Badenian deposits occur up to the present in relicts in the nearby surroundings.

After this layer had been deposited, a long hiatus followed in the Vykopaná chodba. Well documented sediments are found in layers $2 \mathrm{a}$ and $2 \mathrm{~b}(\mid \mathrm{ZH} \mathrm{P}-5)$ from the Middle Pleistocene (U/Th $267 \pm 3$ ka BP, Lundberg et al. 2014) and probably also in some other similar layers. 


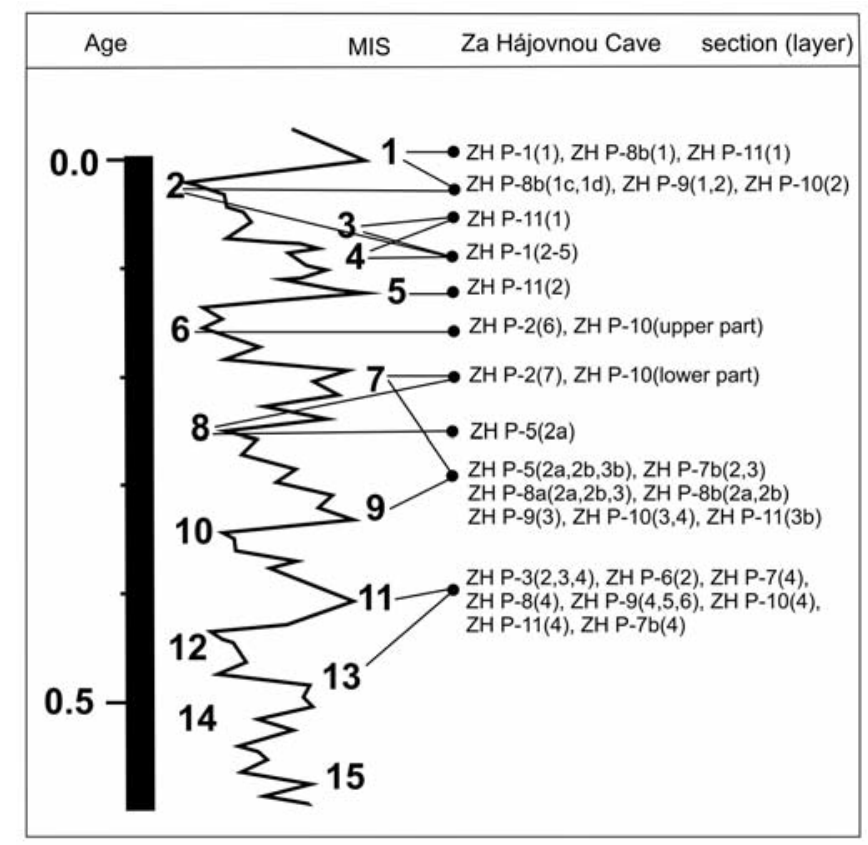

Text-fig. 16. Za Hájovnou Cave. Possible lenght of time of layers of individual sections. This is not a stratigraphical table.

Regarding layers $3 \mathrm{a}$ and $3 \mathrm{~b}$ of the same profile, we can only deduce that they are older. In another area (ZH P-6, layer 2, ZH P-3, layers 3 and 5), however, we found loessic loam underlying layers $2 \mathrm{a}$ and $2 \mathrm{~b}$, from a completely different ecological period, reflecting a dry, colder period. It can't be either ruled out or proved that these layers could theoretically also be located between the debris cone and layers $2 \mathrm{a}$ and $2 \mathrm{~b}$ in the Narozeninová chodba.

Layers $2 \mathrm{a}$ and $2 \mathrm{~b} \mathrm{ZH}$ P-5 continued through the Spojovací chodba to the Narozeninová chodba. They are still present in $\mathrm{ZH} \mathrm{P}-8 \mathrm{a}$, layers $2 \mathrm{a}$ and $2 \mathrm{~b}$ and then in $\mathrm{ZH} \mathrm{P}-8 \mathrm{~b}$, layers $2 \mathrm{a}$ and $2 \mathrm{~b}$. The underlying bed in the Narozeninová chodba is the debris cone (layer 4), on on the basis of large boulders (see also Text-fig. 16). This debris cone divides all the sediments into two groups (groups A and B).

The group of layers above the debris cone (group $2 \mathrm{~A}$ ), as well as the debris cone itself, and the groups of layers below it (group 2 B) originate from a warm period. But they differ in the preservation of bones and the composition of layers. Both phases were then divided by the formation of the debris cone.

The findings of lions (Sabol, this issue) in the sediments of the group 2 A have well documented two different time periods. In the group of sediments A we have therefore two climatically nearly the same but in time different warm periods. The underlying group of sediments (B) documents then the next warm period (interglacial), climatically completely different (Doláková, this issue) from the previous.

There are today numerous sites of this age in Central and Western Europe mostly without palaeontological finds. The picture of Middle Pleistocene stratigraphy is therefore still open for discussion. The conclusions of geological, zoopaleontological, phytopaleontogical and climate research are often contradictory and their correlation with marine sediments or with the Greenland glacier cause difficulties (Meyer 2012, Schreve 2012, Serangeli et al., 2012, Sierralta et al. 2012). Some stratigraphic conclusions take into account the possibility of regional differences in age of identical layers.

According to the official chronostratigraphic chart, the Holsteinian Interglacial should be considered as only one interglacial and included in MIS 11. Sediments and findings of fauna indicate that in the Za Hájovnou cave we have in superposition three warm periods.

\section{Conclusions}

The Za Hájovnou Cave is a former sinkhole. It was active until the beginning of the Cromerian Interglacial Complex. The cave is a typical bear cave from the Middle Pleistocene, so that the greatest number of finds belongs to the species Ursus deningeri. A few of the findings are from other animal species but apart from lions and voles, they have little stratigraphic value.

The most important information from Za Hájovnou Cave lies in the sediments from the Middle Pleistocene. Detailed stratigraphy of the Middle Pleistocene has recently become a topical theme for discussion. The sedimentary sequence of this cave the paleozoological findings and palynology may contribute significantly to this discussion. In the cave, there are fundamentally two different layers, groups (2A and 2B) located in the superposition. The two groups are identical, both from a warm climate but different in their development. However, it is even more complicated. Group 2 A has two stratigraphic classification according to the lion findings (Sabol 2014). In the Narozeninová chodba, both groups (A and B) are separated by a large debris cone.

There are today numerous sites of this age in Central and Western Europe but unfortunately, mostly without palaeontological finds. The picture of Middle Pleistocene stratigraphy is therefore still open for discussion. The conclusions of geological, zoopaleontological, phytopaleontogical and climate research are often contradictory and their correlation with marine sediments or with the Greenland glacier causes difficulties (Meyer 2012, Schreve 2012, Serangeli et al., 2012, Sierralta et al. 2012, Richter and Thieme 2012). Some stratigraphic conclusions take into account the possibility of regional differences in age of identical layers.

According to the official chronostratigraphic chart, the Holsteinian Interglacial should be considered as only one intergacial and included in MIS 11. The findings from Za Hájovnou Cave are somewhat inconsistent with this view. Here it appears that we have maybe two successive interglacials.

In this cave we have in the superposition two complexes of layers from a warm climate, with different rainfall, divided by a large debris cone. The layers all appear to have been formed over an extended time period. The colder climate below the sediments of group A (loessic loam) exist only in the Vykopaná chodba and unfortunately not in the narozeninová chodba. Therefore both profiles in the Vykopaná chodba (ZH P-3 and ZH P-6) with loessic loam sediments in the underlying bed of brown sediment (group A) could only possibly be extended into the Narozeninová chodba. 
There are two main stratigraphic interpretations which may be put forward based on the information contained in this article:

1. The whole complex of layers (group A, group B, debris cone) belong to one interglacial which climatically can be divided into two phases. This contradicts the occurrence of the substantial debris cone between groups A and B, and the assumed extended time period which would have been necessary for the formation of all the layers. The estimated length of the Middle Pleistocene interglacial is not sufficiently long to accommodate this possibility. Sabol's paper (2014) indicates the possibility that layers of group A must be divided into two different time periods according to the lion remains.

2. There cannot have been only one interglacial period. The differences between groups A and B are so great that we must assume there was more than one interglacial. This is evidenced by Sabol's paper (2014) and also that of Doláková (2014). The only contradiction being the fact that if there had been two interglacials, we should have found between them a period of cold climate.

To solve this issue a paper summarizing all the partial conclusions from each participating discipline would be required.

\section{References}

Ábelová, M. (2005): Doprovodná fauna velkých cicavcov medvedej jaskyne „Za Hájovnou“ (Javoříčský kras) [Accompanying Fauna of Large Mammals in "Za Hájovnou" Cave (Javoříčko Karst, Moravia]. - Př́rodovědné studie Muzea Prostějovska, 8: 171-184. (in Slovak)

Čatloš, J., Fejdi, P. (2005): Studium mineralov z jaskynných sedimentov z jaskyne „Za Hájovnou“, Javoříčský kras [Study of minerals from sediments of "Za Hájovnou Cave", Javoříčko Karst, Moravia]. - Př́rodovědné studie Muzea Prostějovska, 8: 59-67. (in Slovak)

Doláková, N. (2005): Palynologická studia v jeskyni „Za Hájovnou“, Javoř́íčský kras [Palynological studies in "Za Hájovnou" Cave, Javoříčko Karst, Moravia]). Př́rodovědné studie Muzea Prostějovska, 8: 83-88. (in Czech)

Doláková, N. (2014): Palynological analysis of sediments from Za Hájovnou Cave. - Acta Mus. Nat. Pragae, Ser. B, Hist. Nat, 70(1-2): 35-42.

Ivanov, M. (2005): Obojživelníci a plazi z lokality „Za Hájovnou" Javoříčský kras [Amphibians and reptiles from the "Za Hájovnou" Cave, Javoříčsko Karst, Moravia]). - Př́rodovědné studie Muzea Prostějovska, 8: 89-108. (in Czech)

Ivanov, M., Vöröš, D. (2014): New research on small mammals (Rodentia: Arvicolinae) from Za Hájovnou Cave (Javoříčko Karst). - Acta Mus. Nat. Pragae, Ser. B, Hist. Nat, 70(1-2): 43-54.

Kadlec, J., Chadima, M., Pruner, P., Schnabl, P. (2005): Paleomagnetické datování sedimentů v jeskyni Za Hájovnou v Javoříčku - předběžné výsledky [Palaeomagnetic dating of sediments in the "Za Hájovnou" Cave, Javoříčko Karst, Moravia]. - Př́rodovědné studie Muzea Prostějovska, 8: 75-82. (in Czech)
Kadlec, J., Č́ížková, K., Šlechta, S. (2014): New updated results of paleomagnetic dating of cave deposits exposed in "Za Hájovnou" Cave, Javoříčko Karst. - Acta Mus. Nat. Pragae, Ser. B, Hist. Nat, 70(1-2): 27-34.

Lundberg, J., Musil, R., Sabol, M. (2014): Sedimentary history of Za Hájovnou Cave (Moravia, Czech Republic): A unique Middle Pleistocene palaeontological site. Quaternary International, 339-340: 11-24. http://dx.doi.org/10.1016/j.quaint.2013.04.006

Meyer, K.-D. (2012): Stratigraphie des Saale-Komplexes in Niedersachsen und die Schöninger Profilen. - In: Behre, K.-E. (ed.): Die chronologische Einordnung der paläolithischen Fundstellen von Schöningen, RömischGermanisches Zentralmuseum, Mainz, pp. 61-76.

Musil, R. (1995a): Large fauna of talus cone at Stránská Skála Hill in Brno. - In: Musil, R. (ed.): Stránská Skála Hill. Excavation of Open-air Sediments 1964-1972. Anthropos, 26 (NS 18): 65-84.

Musil, R. (1995b): The Stránská Skála hill.Its imrtance and significance. - In: Musil, R. (ed.): Stránská Skála Hill. Excavation of Open-air Sediments 1964-1972. Anthropos, 26 (NS 18): 177-208.

Musil, R. (2005a): Jeskyně „Za Hájovnou“, výjimečná lokalita Javoř́ičského krasu [Za Hájovnou Cave, exceptional locality of Javorríčko Karst, Moravia]. - Přírodovědné studie Muzea Prostějovska, 8: 9-42. (in Czech)

Musil, R. (2005b): Metapodia a prstní články medvědů z jeskyně „Za Hájovnou“, Javoříčský kras [Metapodia and phalanges of bears from "Za Hájovnou" Cave, Javoříčko Cave System, Moravia]. - Př́rodovědné studie Muzea Prostějovska, 8: 143-152. (in Czech)

Panoš, V. (1964): Geomorfologický vývoj severní části Hornomoravského úvalu mezi Litovlí a Zábřehem na Moravě [Geomorphological development in the northern part of the Upper Moravian Graben between Litovel and Zábřeh na Moravě]. - Sborník Československé společnosti zeměpisné, 69(2): 99-113. (in Czech)

Panoš, V., Novák, Z., Pek, I., Zapletal, J. (1998): Výskyt mořského spodního badenu jižně od Bouzova [Occurrence of the marine Lower Badenian from south of Bouzov]. Zprávy o geologických výzkumech v roce 1997: 69-70. (in Czech)

Richter, D., Thieme, H.,(2012): One first chronometric date for the lower Palaeolithic occupation at Schöningen 13 I. - In: Behre, K.-E. (ed.): Die chronologische Einordnung der paläolithischen Fundstellen von Schöningen, RömischGermanisches Zentralmuseum, Mainz, pp. 171-182.

Sabol, M. (2005): Štruktúra medvedej populácie z jaskyne „Za Hájovnou“ (Morava, Česká republika) z hladiska zastúpenia pohlaví a vekových štádií: predbežné výsledky [Sex ratios and age structure of bears from the " $\mathrm{Za}$ Hájovnou" Cave (Moravia, Czech Republic: Preliminary results]. - Př́ŕrodovědné studie Muzea Prostějovska, 8: 153-165. (in Slovak)

Sabol, M. (2014): Panthera fossilis (ReIChenau, 1906) (Felidae, Carnivora) from Za Hájovnou Cave (Moravia, Czech Republic): a fossil record from 1987-2007. - Acta Mus. Nat. Pragae, Ser. B, Hist. Nat, 70(1-2): 71-90.

Sabol, M., Zervanová, J. (2014): Cricetus cf. runtonensis (Newton, 1909) (Cricetidae, Rodentia) from the Za 
Hájovnou Cave (Moravia, Czech Republic). - Acta Mus. Nat. Pragae, Ser. B, Hist. Nat, 70(1-2): 55-58.

Schreve, D. (2012): The Reinsdorf Intergaziaal (Schöningen II).Mammalian assemblage in its European context. - In: Behre, K.-E. (ed.): Die chronologische Einordnung der paläolithischen Fundstellen von Schöningen, RömischGermanisches Zentralmuseum, Mainz, pp. 129-142.

Serangeli, J., Böhner, U., Hassmann, H., Conard, N. (2012): Die pleistozänen Fundstellen in Schöningen - eine Einführung. - In: Behre, K.-E. (ed.): Die chronologische Einordnung der paläolithischen Fundstellen von Schöningen, Römisch-Germanisches Zentralmuseum, Mainz, pp. 1-22.

Sierralta, M., Frechen, M., Urban, B. (2012): ${ }^{230} \mathrm{Th} / \mathrm{U}$ dating results from open cast mine Schöningen. - In: Behre, K.-E. (ed.): Die chronologische Einordnung der paläolithischen Fundstellen von Schöningen, Römisch-Germanisches Zentralmuseum, Mainz, pp. 143-154.

Wagner, J. (2005): Morfometrická charakteristika dentálního materiálu medvědů z jeskyně „Za Hájovnou“, Javoříčský kras [Morphometric characteristic of bear dental material from “Za Hájovnou” Cave, Javořričko Karst, Moravia]. Př́rodovědné studie Muzea Prostějovska, 8: 109-142. (in Czech)

Zeman, J. (2005): Geochemie sedimentů jeskyně „Za Hájovnou“, Javoříčský kras [Geochemistry of "Za Hájovnou" Cave sediments in Javoříčko Karst]. - Přírodovědné studie Muzea Prostějovska, 8: 49-58. (in Czech) 